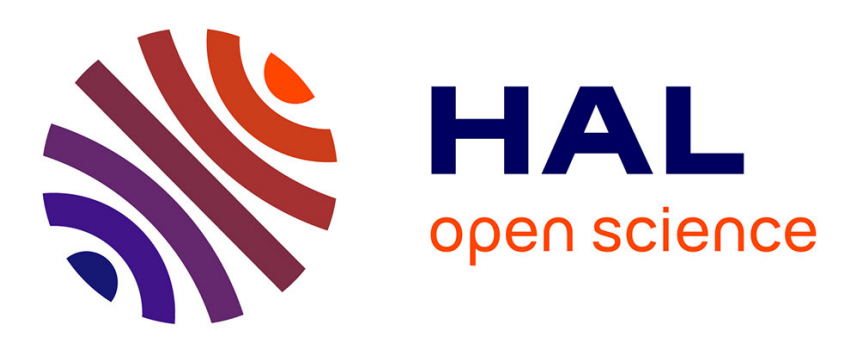

\title{
New sesquiterpene acid and inositol derivatives from Inula montana L.
}

Elnur Garayev, Gaëtan Herbette, Carole Di Giorgio, Philippe Chiffolleau, David Roux, Huguette Sallanon, Evelyne Ollivier, Riad Elias, Béatrice Baghdikian

\section{To cite this version:}

Elnur Garayev, Gaëtan Herbette, Carole Di Giorgio, Philippe Chiffolleau, David Roux, et al.. New sesquiterpene acid and inositol derivatives from Inula montana L.. Fitoterapia, 2017, 120, pp.79-84. 10.1016/j.fitote.2017.05.011 . hal-01614539

\section{HAL Id: hal-01614539 https://hal.science/hal-01614539}

Submitted on 14 May 2018

HAL is a multi-disciplinary open access archive for the deposit and dissemination of scientific research documents, whether they are published or not. The documents may come from teaching and research institutions in France or abroad, or from public or private research centers.
L'archive ouverte pluridisciplinaire HAL, est destinée au dépôt et à la diffusion de documents scientifiques de niveau recherche, publiés ou non, émanant des établissements d'enseignement et de recherche français ou étrangers, des laboratoires publics ou privés. 
New sesquiterpene acid and inositol derivatives from Inula montana $\mathrm{L}$.

Elnur Garayev ${ }^{1}$, Gaëtan Herbette ${ }^{2}$, Carole Di Giorgio ${ }^{3}$, Philippe Chiffolleau ${ }^{4}$, David Roux $^{5}$, Huguette Sallanon ${ }^{5}$, Evelyne Ollivier ${ }^{1}$, Riad Elias ${ }^{1}$, Béatrice Baghdikian ${ }^{1 *}$

${ }^{1}$ Aix Marseille Univ, UMR-MD3, Laboratory of Pharmacognosy and Ethnopharmacology, Faculty of Pharmacy, 27 bld Jean Moulin - CS 30064, 13385 Marseille, France

${ }^{2}$ Aix Marseille Univ, Spectropole, FR1739, Service 511, Campus Saint-Jérome, 13397 Marseille, France.

${ }^{3}$ Aix Marseille Univ, Laboratoire de Mutagenèse Environnementale, IMBE, IFR ECCOREV, Faculty of Pharmacy, 27 bld Jean Moulin- CS 30064, 13385 Marseille, France

${ }^{4}$ Luberon Natural Regional Park, 60, place Jean Jaurès, 84400 Apt, France

${ }^{5}$ Avignon University, Qualisud, UMR 95, F-84000, Avignon, France

*Corresponding author: beatrice.baghdikian@univ-amu.fr

Keywords: Inula montana L., Sesquiterpenes, Inositol derivatives, Anti-inflammatory activity.
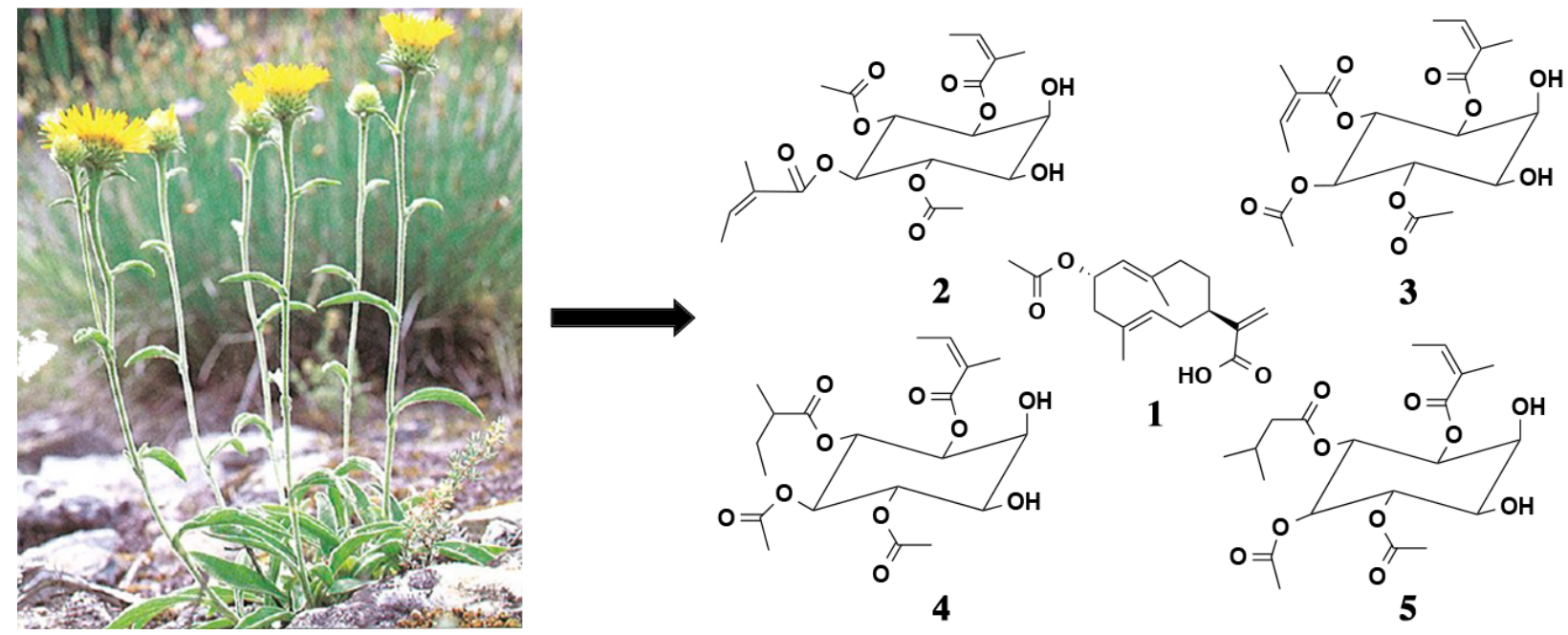

Abstract

A phytochemical investigation of the ethanol extract of leaves and flowers of Inula montana $\mathrm{L}$. led to the isolation of one new sesquiterpene acid called Eldarin (1) and four new inositol derivatives, Myoinositol,1,5-diangelate-4,6-diacetate (2), Myoinositol,1,6-diangelate-4,5-diacetate (3), Myoinositol-1-angelate-4,5-diacetate-6(2-methylbutirate) (4), Myoinositol-1-angelate-4,5-diacetate-6-isovalerate (5) isolated for the first time, along with eleven known compounds described for the first time in Inula montana, 1 $\beta$-Hydroxyarbusculin A (6), Artemorin (7), Santamarin (8), Chrysosplenol C (9), 6-Hydroxykaempferol 3,7-dimethyl ether (10), Reynosin (11), 
Calenduladiol-3-palmitate (12), Costunolide (13), 4-Hydroxy-3,5dimethoxybenzenemethanol (14), 93-Hydroxycostunolide (15) and Hispidulin (16). Structural elucidation has been carried out by spectral methods, such as $1 \mathrm{D}$ and 2D NMR, IR, UV and HR-ESI-MS. These compounds have been tested in vitro for antiinflammatory and cytotoxic activity on macrophages RAW 264.7. As a result, compounds $2,3,7,13,14,15$ and 16 showed a release of $\mathrm{NO}$ with $\mathrm{IC}_{50}$ value $<30$ $\mu \mathrm{M}$ on macrophages.

\section{Introduction}

The Inula genus comprises more than one hundred species, mainly distributed in Africa, Asia and Europe, predominantly, in the Mediterranean Area. Compounds isolated from the species of this genus are mono-, sesqui-, di- and triterpenes, flavonoids and inositol derivatives. Cyclic sesquiterpenes are the predominant constituents of Inula genus [1-3]. Alcoholic and oil preparations of the flowering aerial parts of this plant are widely used in the traditional medicine of Provence (France) in the treatment of hematomas, as well as Arnica montana L. [4]. However, its phytochemical composition has been poorly investigated [5-8]. Only six sesquiterpene lactones, four free flavonoid aglycones and volatile composition have been reported in Inula montana L. until now [5,6].

Antioxidant and anti-protozoocidal activities of Inula montana extracts have been previously reported as well. No anti-inflammatory activity has been investigated comparing to Inula cappa or Inula wissmanniana [3,7-9]. In this study, we describe the isolation of sixteen compounds for the first time from Inula montana L., including five new ones. The anti-inflammatory activity of the isolated compounds has been also evaluated.

\section{Experimental part}

\subsection{General}

Optical rotations were measured using Anton Paar polarimeter $(1=10 \mathrm{~mm}, \varnothing=5$ mm, Ref. 279986.05). UV spectra were recorded on Shimadzu UV-1650pc spectrophotometer. IR spectra were recorded on Bruker Vertex 70 FT-IR with ATR module. 1D and 2D NMR spectra were recorded on Bruker AVANCE III 600 
spectrometer $\left({ }^{1} \mathrm{H} 600.13 \mathrm{MHz}\right)$ with tetramethylsilane (TMS) as internal standard at $300 \mathrm{~K}$. Chemical shifts $(\delta)$ were expressed in ppm with TMS as an internal reference. HR-ESI-MS was performed on SYNAPT G2 HDMS (Waters) spectrometer. UHPLC was performed on Agilent 1290 liquid chromatograph equipped with a Zorbax Eclipse Plus, C18 $(100 \times 2.1 \mathrm{~mm}, 2.8 \mu \mathrm{m})($ Agilent $)$ column. HPLC was performed on Agilent 1200 liquid chromatograph equipped with a Luna C18 $(150 \times 4.6 \mathrm{~mm}, 3$ $\mu \mathrm{m})$ column. Preparative HPLC was performed on Gilson PLC2020 with a Luna C18 $(150 \times 21.2 \mathrm{~mm}, 3 \mu \mathrm{m})$ column (Phenomenex). Flash chromatography was performed using a Teledyn Isco CombiFlash Rf 200 (USA). TLC analysis was performed on Silica $\mathrm{F}_{254}$ plates (Merck).

The positive control dexamethasone, phosphate tampon, dimethyl sulfoxide, RAW 264.7 cells and Lyposaccharides (LPS) of E.coli were purchased from SigmaAldrich. Griess reagent was purchased from Promega.

\subsection{Plant material}

The plant I. montana was collected in Merindol (Luberon Natural Regional Park, France) in June 2015 and identified by Dr. Didier Morisot from the University of Montpellier and by Mr. Laurent Michel from Luberon Natural Reserve. Voucher specimens of leaves (IMFF151) and flowers (IMFLF151) were deposited in the Laboratory of Pharmacognosy of Aix Marseille University (Marseille, France).

\subsection{Extraction and isolation}

The air-dried plant materials: leaves $(0.2 \mathrm{~kg})$ and flowers $(0.2 \mathrm{~kg})$, were extracted separately with EtOH $95 \%(\mathrm{v} / \mathrm{v})(1.2 \mathrm{~L} \times 3)$, by percolation at room temperature for $18 \mathrm{~h}$, to afford crude extracts E2 (leaves, $8.6 \mathrm{~g}$ ) and L2 (flowers, 23.7 g). After concentration in vacuo, each extract was suspended in $\mathrm{H}_{2} \mathrm{O}$ and partitioned by petroleum ether and dichloromethane successively, to provide a petroleum ether E2P (2.1 g) and dichloromethane E2D (1.0 g) extracts for leaves and petroleum ether L2P (4.4 g) and dichloromethane L2D (0.7 g) extracts for flowers.

The leaves dichloromethane extract E2D (0.9 g) was subjected to reversed phase silica gel $(\mathrm{C} 18,100 \mathrm{~g})$ flash chromatography and eluted with water/methanel MeOH- $\mathrm{H}_{2} \mathrm{O}(0-30 \min 35-85 \% \mathrm{MeOH}, 30-31 \min 85-100 \% \mathrm{MeOH}, 31-35 \min 100 \%$ $\mathrm{MeOH}(\mathrm{v} / \mathrm{v})$, flow rate: $40 \mathrm{~mL} / \mathrm{min}$ ) to afford three fractions (E2D1), (E2D2), (E2D3) 
and three compounds $6(0.3 \mathrm{mg}), 7(19.2 \mathrm{mg})$ and $\mathbf{8}(0.3 \mathrm{mg})$. Fraction E2D1 (50.5 $\mathrm{mg}$ ) was subjected to preparative HPLC $(\mathrm{C} 18,3 \mu \mathrm{m}, 150 \times 21.2 \mathrm{~mm}$, flow rate 10.6 $\mathrm{mL} / \mathrm{min}$, wavelength $225 \mathrm{~nm}$ ) using $\mathrm{MeOH}-\mathrm{H}_{2} \mathrm{O}$ system (52-48, v/v) which gave two compounds: $2(12 \mathrm{mg})$ and $\mathbf{3}(12.7 \mathrm{mg})$. Fraction E2D2 (50.7 $\mathrm{mg})$ was separated by preparative HPLC $(\mathrm{C} 18,3 \mu \mathrm{m}, 150 \times 21.2 \mathrm{~mm}$, flow rate $10.6 \mathrm{~mL} / \mathrm{min}$, wavelength $210 \mathrm{~nm}$ ) using $\mathrm{MeOH}-\mathrm{H}_{2} \mathrm{O}$ system (42-58, v/v) which afforded compounds 9 (0.3 $\mathrm{mg}), \mathbf{1 0}(0.2 \mathrm{mg})$ and $\mathbf{1 1}(0.5 \mathrm{mg})$. Fraction E2D3 (12.7 mg) has been found to be as the mix of two compounds $\mathbf{4}$ and $\mathbf{5}$.

The flowers petroleum ether extract L2P $(2.1 \mathrm{~g})$ was subjected to silica gel (24g) flash chromatography and eluted with n hexane/hyl ace n-Hexane-Ethyl acetate (EtOAc) (0-30 min 0-20\% EtOAc, 30-42 min 20-100\% EtOAc, 42-50 min $100 \%$ EtOAc (v/v), flow rate $20 \mathrm{~mL} / \mathrm{min})$ to give three fractions (L2P1), (L2P2) and (L2P3). Fraction L2P1 (350 mg) was subjected to silica gel (24g) flash chromatography and eluted with toluene/EtOAc (0 - 20 min 0\% EtOAc, 20 - 45 min 0-5\% EtOAc, 45 - 50 min 5\% EtOAc, 50 - 55 min 5 - $100 \%$ EtOAc, 55 - 62 min $100 \%$ EtOAc (v/v), flow rate $20 \mathrm{~mL} / \mathrm{min})$ to afford compound $\mathbf{1 2}(23,2 \mathrm{mg})$. Fraction L2P2 (48 mg) was separated by HPLC using as elment water/methanel (C18, $3 \mu \mathrm{m}$, $150 \times 21.2 \mathrm{~mm}, 0-60 \mathrm{~min}$, flow rate $21.2 \mathrm{~mL} / \mathrm{min}$, wavelength $210 \mathrm{~nm}$ ) using MeOH- $\mathrm{H}_{2} \mathrm{O}$ system (52-48, v/v) which gave compound 13 (9.4 mg). Fraction L2P3 $(50 \mathrm{mg})$ was separated by HPLC $(\mathrm{C} 18,3 \mu \mathrm{m}, 150 \times 21.2 \mathrm{~mm}$, flow rate $21.2 \mathrm{~mL} / \mathrm{min}$, wavelength $210 \mathrm{~nm}$ ) using $\mathrm{MeOH}-\mathrm{H}_{2} \mathrm{O}$ system $(0-20 \min 40-100 \% \mathrm{MeOH}, 20-$ $30 \mathrm{~min} 100 \% \mathrm{MeOH})$ which gave compound 1 (16.2 mg).

Fraction L2D (0.6 g) was subjected to reversed phase silica gel $(\mathrm{C} 18,100 \mathrm{~g})$ flash chromatography and eluted with the same conditions as the fraction E2D to afford one fraction (L2D1) and two compounds $14(15 \mathrm{mg})$ and $15(5 \mathrm{mg})$. The fraction L2D1 was subjected to HPLC $(\mathrm{C} 18,3 \mu \mathrm{m}, 150 \times 21.2 \mathrm{~mm}, 0-60 \mathrm{~min}$, flow rate $21.2 \mathrm{~mL} / \mathrm{min}$, wavelength $210 \mathrm{~nm}$ ) using $\mathrm{MeOH}-\mathrm{H}_{2} \mathrm{O}$ system $(50-50, \mathrm{v} / \mathrm{v})$ which gave compound $\mathbf{1 6}(12.3 \mathrm{mg})$.

2.3.1 Eldarin (1) White amorphous powder; $[\alpha]_{D}^{25}$ - 40,11 (c 0.53, MeOH); UV $\lambda_{\max }(\log \varepsilon) 205 \mathrm{~nm}(3.4 ; \mathrm{MeOH}) ; \mathrm{IR}(\mathrm{ATR}) v_{\max } 3440,3055,2926,2858,1724$, 
1693, 1621, 1432, 1369, 1241, 1018, 956, $735 \mathrm{~cm}^{-1} ;{ }^{1} \mathrm{H}$ and ${ }^{13} \mathrm{C}$ NMR data, see Table 1; HR-ESI-MS: m/z $293.1748[\mathrm{M}+\mathrm{H}]^{+}$(calcd. for $\mathrm{C}_{17} \mathrm{H}_{25} \mathrm{O}_{4}{ }^{+}$: 293.1747).

2.3.2 Myoinositol,1,5-diangelate-4,6-diacetate (2) Yellow oil; $[\alpha]_{D}^{25}-8,35$ (c 1.1, MeOH); UV $\lambda_{\max }(\log \varepsilon) 217 \mathrm{~nm}(3.6 ; \mathrm{MeOH})$; IR (ATR) $v_{\max } 3472,3022$, 2928, 1751, 1719, 1647, 1457, 1365, 1223, 1138, 1083, $1037 \mathrm{~cm}^{-1} ;{ }^{1} \mathrm{H}$ and ${ }^{13} \mathrm{C}$ NMR data, see Tables 2 and 3; HR-ESI-MS: $\mathrm{m} / \mathrm{z} 429.1756[\mathrm{M}+\mathrm{H}]^{+}$(calcd. for $\mathrm{C}_{20} \mathrm{H}_{29} \mathrm{O}_{10}{ }^{+}$: 429.1755).

2.3.3 Myoinositol,1,6-diangelate-4,5-diacetate (3) Yellow oil; $[\alpha]_{D}^{25}-20,04$ (c 0.4, MeOH); UV $\lambda_{\max }(\log \varepsilon) 217 \mathrm{~nm}(4.0 ; \mathrm{MeOH})$; IR (ATR) $v_{\max } \sim 3373,2926$, 1706, 1645, 1457, 1381, 1352, 1230, 1146, 1084, $1042 \mathrm{~cm}^{-1} ;{ }^{1} \mathrm{H}$ and ${ }^{13} \mathrm{C}$ NMR data, see Tables 2 and 3; HR-ESI-MS: $\mathrm{m} / \mathrm{z} 429.1757[\mathrm{M}+\mathrm{H}]^{+}$(calcd. for $\mathrm{C}_{20} \mathrm{H}_{29} \mathrm{O}_{10}{ }^{+}$: 429.1755).

2.3.4 Myoinositol-1-angelate-4,5-diacetate-6-(2-methylbutirate) (4) and myoinositol-1-angelate-4,5-diacetate-6-isovalerate (5) Yellow oil; IR (ATR) $v_{\max }$ 3473, 2964, 2933, 1746, 1647, 1460, 1366, 1226, 1152, $1036 \mathrm{~cm}^{-1} ;{ }^{1} \mathrm{H}$ and ${ }^{13} \mathrm{C}$ NMR data, see Tables 2 and 3; HR-ESI-MS: $\mathrm{m} / \mathrm{z} 431.1908[\mathrm{M}+\mathrm{H}]^{+}$(calcd. for $\mathrm{C}_{20} \mathrm{H}_{31} \mathrm{O}_{10}{ }^{+}$: 431.1912).

Table 1

NMR data of compound 1. ${ }^{1} \mathrm{H}(600 \mathrm{MHz}),{ }^{13} \mathrm{C}(150 \mathrm{MHz})$ in $\mathrm{CDCl}_{3}$ at $300 \mathrm{~K}$.

\begin{tabular}{|c|c|c|}
\hline No. & $\delta_{1 \mathrm{H}}$ & $\delta_{13 \mathrm{C}}$ \\
\hline $1 \mathrm{ax}$ & $5.03($ br d 10.6) & 128.1 \\
\hline $2 \mathrm{ax}$ & $5.68($ br td $10.6,5.3)$ & 69.7 \\
\hline $3 a x$ & $2.18($ br t 11.1) & 44.7 \\
\hline 3 eq & $2.58(\mathrm{dd} 11.1,5.3)$ & \\
\hline 4 & - & 134.4 \\
\hline $5 \mathrm{ax}$ & $5.34(\mathrm{t} 7.5)$ & 129.5 \\
\hline $6 \mathrm{ax}$ & $1.94(\operatorname{td} 12.6,7.5)$ & 32.4 \\
\hline $6 e q$ & $2.22(\mathrm{~m})$ & \\
\hline $7 \mathrm{ax}$ & $2.39(\mathrm{~m})$ & 39.4 \\
\hline $8 \mathrm{ax}$ & $1.86($ br td $13.8,3.6)$ & 34.6 \\
\hline $8 \mathrm{eq}$ & $1.67(\mathrm{~m})$ & \\
\hline $9 \mathrm{ax}$ & $1.77($ br td $14.0,4.3)$ & 34.6 \\
\hline 9eq & $2.32($ br d 13.8$)$ & \\
\hline 10 & & 140.3 \\
\hline 11 & & 146.0 \\
\hline 12 & & 171.8 \\
\hline \multirow[t]{2}{*}{13} & $6.29(\mathrm{br} \mathrm{s})$ & 125.4 \\
\hline & $5.66(\mathrm{br} \mathrm{s})$ & \\
\hline 14 & $1.86(\mathrm{~s})$ & 22.5 \\
\hline 15 & $1.59(\mathrm{~s})$ & 16.8 \\
\hline \multirow[t]{2}{*}{ 2- $\mathrm{CH}_{3} \mathrm{CO}_{2}$} & $2.05(\mathrm{~s})$ & 21.5 \\
\hline & - & 171.4 \\
\hline
\end{tabular}

$\delta$ in ppm, br: broad, s: singlet, d: doublet, t: triplet, q: quadruplet, m: multiplet, $(J \mathrm{~Hz})$ 
Table 2

NMR data of compounds $\mathbf{2}, \mathbf{3 , 4}$ and $\mathbf{5} .{ }^{1} \mathrm{H}(600 \mathrm{MHz})$ in $\mathrm{CD}_{3} \mathrm{OD}$ at $300 \mathrm{~K}$

\begin{tabular}{|c|c|c|c|c|}
\hline No. & 2 & 3 & 4 & 5 \\
\hline 1 & $5.02(\mathrm{dd}, 10.0,2.6)$ & $5.09(\mathrm{dd}, 10.0,2.6)$ & $5.05(\mathrm{dd}, 10.0,2.6)$ & $5.02(\mathrm{dd}, 10.0,2.6)$ \\
\hline 2 & $4.23(\mathrm{t}, 2.6)$ & $4.20(\mathrm{t}, 2.6)$ & $4.16(\mathrm{t}, 2.6)$ & $4.18(\mathrm{t}, 2.6)$ \\
\hline 3 & $3.84(\mathrm{dd}, 10.0,2.6)$ & $3.83(\mathrm{dd}, 10.0,2.6)$ & $3.82(\mathrm{dd}, 10.0,2.6)$ & $3.81(\mathrm{dd}, 10.0,2.6)$ \\
\hline 4 & $5.44(\mathrm{t}, 10.0)$ & $5.40(\mathrm{t}, 10.0)$ & $5.37(\mathrm{t}, 10.0)$ & $5.37(\mathrm{t}, 10.0)$ \\
\hline 5 & $5.26(\mathrm{t}, 10.0)$ & $5.22(\mathrm{t}, 10.0)$ & $5.19(\mathrm{t}, 10.0)$ & $5.16(\mathrm{t}, 10.0)$ \\
\hline 6 & $5.68(\mathrm{t}, 10.0)$ & $5.73(\mathrm{t}, 10.0)$ & $5.65(\mathrm{t}, 10.0)$ & $5.65(\mathrm{t}, 10.0)$ \\
\hline & \multicolumn{4}{|c|}{ Ang-1 } \\
\hline 1 & - & - & - & - \\
\hline 2 & - & - & - & - \\
\hline 3 & $6.18(\mathrm{qq}, 7.5,1.5)$ & $6.15(\mathrm{qq}, 7.5,1.5)$ & $6.15(\mathrm{qq}, 7.5,1.5)$ & $6.18(\mathrm{qq}, 7.5,1.5)$ \\
\hline 4 & $1.96(\mathrm{dq}, 7.5,1.5)$ & 1.94 (ov) & 1.94 (ov) & $1.97(\mathrm{dq}, 7.5,1.5)$ \\
\hline \multirow[t]{2}{*}{5} & 1.86 (br quint, 1.5$)$ & 1.83 (br quint, 1.5 ) & 1.83 (br quint, 1.5) & 1.85 (br quint, 1.5 ) \\
\hline & \multicolumn{4}{|c|}{ Ac- 4} \\
\hline 1 & - & - & - & - \\
\hline 2 & $2.01(\mathrm{~s})$ & $2.04(\mathrm{~s})$ & $2.04(\mathrm{~s})$ & $2.03(\mathrm{~s})$ \\
\hline & \multicolumn{2}{|c|}{ Ang-5 } & \multicolumn{2}{|c|}{ Ac-5 } \\
\hline 1 & - & - & - & - \\
\hline 2 & - & $1.90(\mathrm{~s})$ & $1.90(\mathrm{~s})$ & $1.95(\mathrm{~s})$ \\
\hline 3 & $6.13(\mathrm{qq}, 7.5,1.5)$ & & & \\
\hline 4 & 1.92 (ov) & & & \\
\hline \multirow[t]{2}{*}{5} & 1.80 (br quint, 1.5 ) & & & \\
\hline & Ac-6 & Ang-6 & 2MB-6 & iVal-6 \\
\hline 1 & - & - & - & - \\
\hline 2 & $1.93(\mathrm{~s})$ & - & $2.29(\mathrm{~m})$ & $\begin{array}{l}2.12(\mathrm{dd}, 14.9,7.4) \\
2.09(\mathrm{dd}, 14.9,6.8)\end{array}$ \\
\hline 3 & & $6.09(\mathrm{qq}, 7.5,1.5)$ & $1.58(\mathrm{~m}), 1.38(\mathrm{~m})$ & $1.96(\mathrm{~m})$ \\
\hline 4 & & $1.88((\mathrm{dq}, 7.5,1.5)$ & $0.83(\mathrm{t}, 7.4)$ & $0.89(\mathrm{~d}, 6.7)$ \\
\hline 5 & & 1.77 (br quint, 1.5 ) & $1.03(\mathrm{~d}, 7.0)$ & $0.89(\mathrm{~d}, 6.7)$ \\
\hline
\end{tabular}

$\delta$ in ppm, br: broad, s: singlet, d: doublet, t: triplet, q: quadruplet, m: multiplet, ov: overlapped $(J \mathrm{~Hz})$

Table 3

NMR data of compounds $2, \mathbf{3}, \mathbf{4}$ and $\mathbf{5} .{ }^{13} \mathrm{C}(150 \mathrm{MHz})$ in $\mathrm{CD}_{3} \mathrm{OD}$ at $300 \mathrm{~K}$.

\begin{tabular}{|c|c|c|c|c|}
\hline No. & 2 & 3 & 4 & 5 \\
\hline 1 & 73.0 & 72.6 & 72.6 & 72.6 \\
\hline 2 & 71.1 & 71.0 & 71.0 & 70.9 \\
\hline 3 & 70.8 & 70.5 & 70.5 & 70.4 \\
\hline 4 & 73.9 & 73.7 & 73.8 & 73.8 \\
\hline 5 & 72.4 & 72.8 & 72.7 & 72.8 \\
\hline \multirow[t]{2}{*}{6} & 71.4 & 70.5 & 70.7 & 70.7 \\
\hline & \multicolumn{4}{|c|}{ Ang-1 } \\
\hline 1 & 168.3 & 167.9 & 167.6 & 167.8 \\
\hline 2 & 128.6 & 128.3 & 128.1 & 128.1 \\
\hline 3 & 140.4 & 140.1 & 140.9 & 140.6 \\
\hline 4 & 15.9 & 15.7 & 16.0 & 16.0 \\
\hline \multirow[t]{2}{*}{5} & 20.6 & 20.3 & 20.5 & 20.5 \\
\hline & \multicolumn{4}{|c|}{ Ac-4 } \\
\hline 1 & 172.0 & 171.8 & 171.8 & 171.7 \\
\hline \multirow[t]{2}{*}{2} & 20.9 & 20.6 & 20.6 & 20.6 \\
\hline & \multicolumn{2}{|c|}{ Ang-5 } & \multicolumn{2}{|c|}{ Ac-5 } \\
\hline 1 & 168.0 & 171.2 & 171.1 & 171.1 \\
\hline 2 & 128.4 & 20.3 & 20.5 & 20.5 \\
\hline 3 & 140.2 & & & \\
\hline 4 & 16.1 & & & \\
\hline \multirow[t]{2}{*}{5} & 20.5 & & & \\
\hline & Ac-6 & Ang-6 & 2MB-6 & iVal-6 \\
\hline 1 & 171.3 & 167.7 & 176.5 & 172.9 \\
\hline 2 & 20.7 & 128.3 & 42.3 & 42.3 \\
\hline 3 & & 139.6 & 27.3 & 26.4 \\
\hline 4 & & 15.5 & 11.7 & 22.3 \\
\hline 5 & & 20.2 & 16.9 & 22.3 \\
\hline
\end{tabular}

$\delta$ in ppm, br: broad, s: singlet, d: doublet, t: triplet, q: quadruplet, m: multiplet, ov: overlapped $(J \mathrm{~Hz})$ 


\subsection{Anti-inflammatory and cytotoxicity assays}

In vitro anti-inflammatory assay is based on the ability of immortalized mouse macrophages RAW 264.7 to generate a strong inflammatory response leading to NO release, after stimulation by antigens of $E$. coli. Mouse macrophages were seeded into 48 -well tissue culture plates at the concentration of $1.10^{5}$ cells $/ \mathrm{ml}(200 \mu 1 /$ well $)$ for 24 hours at $37^{\circ} \mathrm{C}\left(5 \% \mathrm{CO}_{2}\right)$. At the end of the incubation period, the culture medium was replaced by $200 \mu \mathrm{l}$ of medium containing appropriate concentrations of evaluated compound, and cells were incubated at $37^{\circ} \mathrm{C}\left(5 \% \mathrm{CO}_{2}\right)$ for one hour. Experiments were performed in duplicate and dexamethasone was used as a positive control at the concentrations of $1,5,10,50$ and $100 \mu \mathrm{M}$. At the end of the incubation period, proinflammatory LPS from E.coli were added to the cell cultures $(1 \mu \mathrm{g} / \mathrm{ml})$. Then the cells were incubated at $37^{\circ} \mathrm{C}\left(5 \% \mathrm{CO}_{2}\right)$ for 18 hours. NO release was measured in the culture supernatant by the Griess reaction: $50 \mu 1$ of the supernatants were transferred into the 96-well tissue culture plate, and $50 \mu 1$ of the Griess modified reagent were added into each well. After a 15 min period at room temperature, Optical Density (OD) of each well was read at $540 \mathrm{~nm}$ by fluorescence - luminescence reader Infinite M200 Pro (TECAN). Results obtained for wells, treated with evaluated compound, were compared to untreated control wells (DMSO, 100\% viability) and converted into the percentage values.

Cell viability was measured to validate this assay: the WST-1 vital dye reagent was used to measure mitochondrial respiration. For this purpose, the culture medium was decanted and $50 \mu \mathrm{l}$ of the WST-1 reagent (1/10 dilution in phosphate buffer) were added into each well. After a $30 \mathrm{~min}$ incubation period at $37^{\circ} \mathrm{C}\left(5 \% \mathrm{CO}_{2}\right)$, OD of each well was read at $450 \mathrm{~nm}$ by a fluorescence - luminescence reader Infinite M200 Pro (TECAN). The results obtained for wells, treated with evaluated compound, were compared to untreated control wells (DMSO, 100\% viability) and converted into the percentage values.

Inhibition of NO release and inhibition of cell viability were expressed as percentages comparing to the negative controls:

Percentage of NO release or cell viability $=\frac{100 \times(\text { OD of test well }- \text { OD of blank })}{\text { OD of DMSO control }- \text { OD of blank }}$ 
The concentrations of the test material causing respectively a $50 \%$ decrease of NO release $\left(\mathrm{IC}_{50 \text {-NO release }}\right)$ and a $50 \%$ decrease of cell viability $\left(\mathrm{IC}_{50 \text {-cell viability }}\right)$ were calculated through non-linear regression analysis using software Tablecurve Version 2.0. The anti-inflammatory ratio was defined as the ratio between anti-inflammatory activity and toxicity. It was expressed as follows:

Anti-inflammatory ratio $=\mathrm{IC}_{50}$ cell viability $/ \mathrm{IC}_{50} \mathrm{NO}$ release

\section{Results and Discussion}

One new sesquiterpene acid, called Eldarin (1), four new inositol derivatives, Myoinositol,1,5-diangelate-4,6-diacetate (2), Myoinositol,1,6-diangelate-4,5diacetate (3), Myoinositol-1-angelate-4,5-diacetate-6-(2-methylbutirate) Myoinositol-1-angelate-4,5-diacetate-6-isovalerate (5), together with eleven

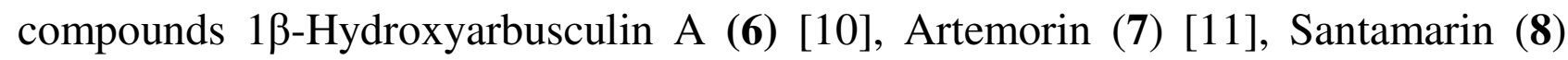
[12], Chrysosplenol C (9) [13], 6-Hydroxykaempferol 3,7-dimethyl ether (10) [14], Reynosin (11) [15], Calenduladiol-3-palmitate (12) [16], Costunolide (13) [17], 4Hydroxy-3,5-dimethoxybenzenemethanol (14) [18] and 9ß-Hydroxycostunolide (15) [19] have been isolated for the first time from leaves and flowers of I. montana. Among the known compounds, compounds $\mathbf{6}$ and $\mathbf{7}$ have been obtained from Inula genus for the first time [1,2]. Known compounds have been identified by comparison of their spectroscopic data with those in the literature. Inositol derivatives with hemiterpenic acid moieties has been already described in Inula cappa, but they are not frequently found in genus Inula [3, 20].

Previously, six sesquiterpene lactones [4] have been described in Inula montana L. by Gonzalez et al. (2001), however, in our study, we haven't isolated any of these reported sesquiterpene lactones. On the other hand, only one flavonoid aglycone, Hispidulin (16) [21], reported by Reynaud et al. (1999) has been isolated and identified in our study [6]. 


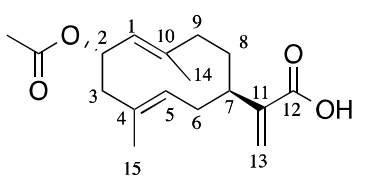

1

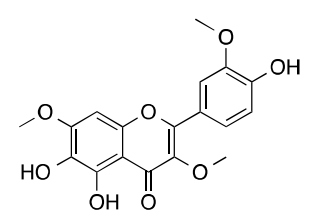

9

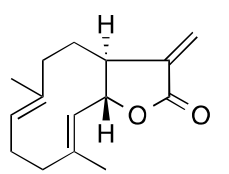

13

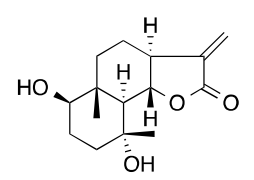

6

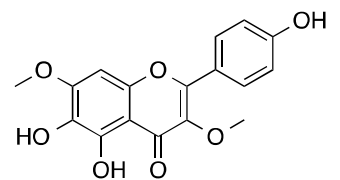

10

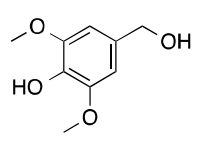

14

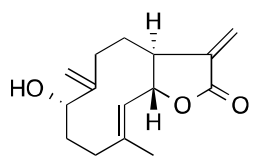

7

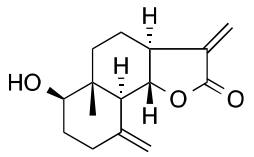

11

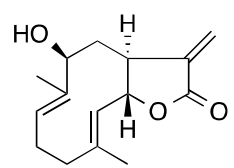

15

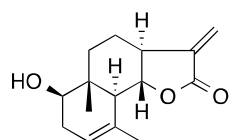

8

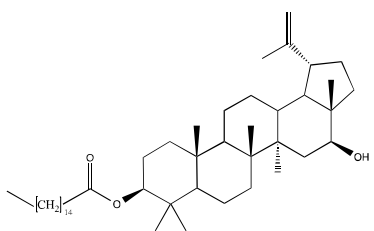

12

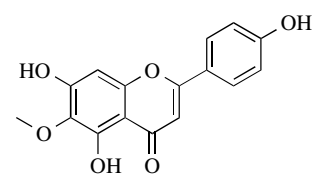

16

Fig. 1. Structures of the isolated compounds 1, 6-16 from I. montana.

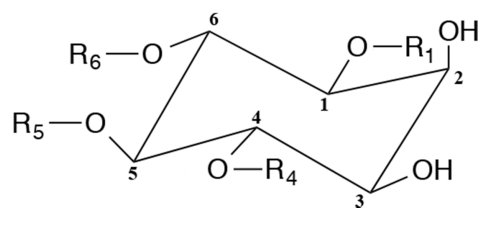

\begin{tabular}{ccccc}
\hline & $\mathrm{R}_{1}$ & $\mathrm{R}_{4}$ & $\mathrm{R}_{5}$ & $\mathrm{R}_{6}$ \\
\hline $\mathbf{2}$ & Ang & Ac & Ang & Ac \\
$\mathbf{3}$ & Ang & Ac & Ac & Ang \\
$\mathbf{4}$ & Ang & Ac & Ac & $2 \mathrm{MB}$ \\
$\mathbf{5}$ & Ang & Ac & Ac & iVal \\
\hline
\end{tabular}
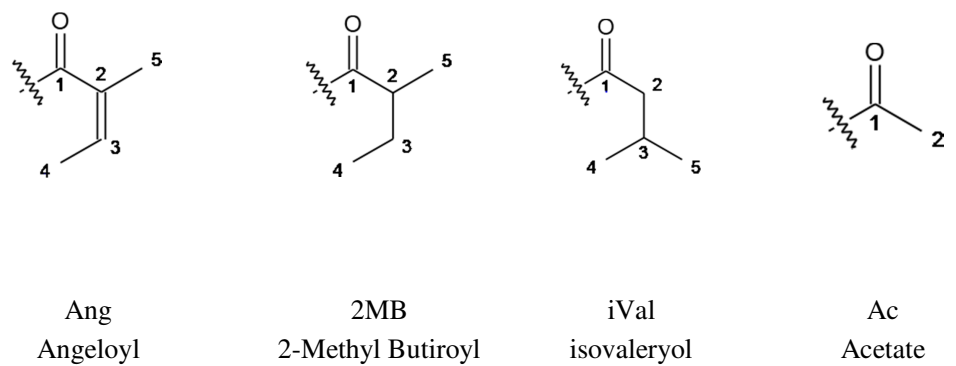

Ac
Acetate

Fig. 2. Structures of the isolated inositol derivatives 2-5 from I. montana.

Compound 1 (Fig. 1) has been obtained as a white amorphous powder. Its molecular formula $\mathrm{C}_{17} \mathrm{H}_{24} \mathrm{O}_{4}$ has been established by positive HR-ESI-MS, which gave a pseudo-molecular ion peak at $\mathrm{m} / \mathrm{z} 293.1748[\mathrm{M}+\mathrm{H}]^{+}$(calcd. for $\mathrm{C}_{17} \mathrm{H}_{25} \mathrm{O}_{4}{ }^{+}$ 293.1747), with the existence of six degrees of unsaturation. The IR spectrum suggested the presence of carbonyl acid (1693, 1241 and $\left.3440 \mathrm{~cm}^{-1}\right)$ and acetate group (1724 and $1241 \mathrm{~cm}^{-1}$ ). The ${ }^{13} \mathrm{C}$ and edited-HSQC spectra gave seventeen carbon resonances with the presence of five quaternary carbons including two carbonyls (171.8, 170.9 ppm) and three ethylenic carbons (146.0, 140.3, 134.4 ppm), 
four methines including two olefinic carbons $(129.5,128.1 \mathrm{ppm})$, one oxygenated $\mathrm{sp}^{3}$ carbon (69.7 ppm), one $\mathrm{sp}^{3}$ carbon (39.4 ppm), five methylenes including one methylene $\mathrm{sp}^{2}$ carbon (125.4 ppm), four methylene $\mathrm{sp}^{3}$ carbons $(44.7,34.6,34.6$, $32.4 \mathrm{ppm})$, three methyls $(22.5,21.5,16.8 \mathrm{ppm})$. The ${ }^{1} \mathrm{H}$ NMR spectrum indicated the presence of one methylene $6.29 \mathrm{ppm}$ (br s), and $5.66 \mathrm{ppm}$ (br s), one methine bearing by an oxygen $5.68 \mathrm{ppm}$ (br td, $J$ 10.6, 5.3), two ethylenic protons 5.34 (t 7.5) and $5.03 \mathrm{ppm}$ (br d $J$ 10.6), four methylenes 2.58 (dd $J 11.1,5.3$ ) and 2.18 (br t $J 11.1$ ), $2.22(\mathrm{~m})$ and $1.94(\operatorname{td} J 12.6,7.5), 1.86(\mathrm{br} \operatorname{td} J 13.8,3.6)$ and $1.67(\mathrm{~m}), 2.32(\mathrm{br} \mathrm{d} J$ 13.8) and 1.77 (br td $J$ 14.0, 4.3), one methine 2.39 (m), three methyls $1.86(\mathrm{~s}), 1.59$ (s) which one from acetate group 2.05 (s). The spectroscopic data suggested a germacrene skeleton: the COSY $\left(\mathrm{H}_{1}-\mathrm{H}_{2}, \mathrm{H}_{2}-\mathrm{H}_{3}, \mathrm{H}_{5}-\mathrm{H}_{6}, \mathrm{H}_{6}-\mathrm{H}_{7}, \mathrm{H}_{7}-\mathrm{H}_{8}, \mathrm{H}_{8}-\mathrm{H}_{9}\right)$ and the HMBC $\left(\mathrm{H}_{2}-\mathrm{C}_{10}, \mathrm{H}_{15}-\mathrm{C}_{3}, \mathrm{H}_{15}-\mathrm{C}_{5}, \mathrm{H}_{14}-\mathrm{C}_{9}, \mathrm{H}_{14}-\mathrm{C}_{1}\right)$ correlations (Fig. 3) had to define a ten carbon ring. The second moiety with based on $\mathrm{HMBC}$ correlations $\left(\mathrm{H}_{13}-\mathrm{C}_{11}, \mathrm{H}_{13^{-}}\right.$ $\mathrm{C}_{12}, \mathrm{H}_{13}-\mathrm{C}_{7}$ ) defined an isobutenic acid connected to the $\mathrm{C}_{7}$ on the ten carbons ring. An acetate moiety was observed and connected to the $\mathrm{C}_{2}$ on the ten carbons ring by the presence of the ${ }^{3} J$ HMBC correlation $\left(\mathrm{H}_{2}-\mathrm{COO}\right)$. The proton $\mathrm{H}_{6 \mathrm{ax}}$ at $1.94(\operatorname{td} J$ 12.6, 7.5) show a ${ }^{3} \mathrm{~J}$ trans coupling constant of $12.6 \mathrm{~Hz}$ with $\mathrm{H}_{7}$ in axial position at 2.39 (m) and the proton $\mathrm{H}_{2}$ at 5.68 (br td $J$ 10.6, 5.3) show two ${ }^{3} \mathrm{~J}$ trans coupling constant of $10.6 \mathrm{~Hz}$ with $\mathrm{H}_{1}$ at 5.03 (br d $J$ 10.6) and $\mathrm{H}_{3 \mathrm{ax}}$ at 2.18 (br t $J 11.1$ ), so $\mathrm{H}_{2}$ is in axial position. NOESY spectra showed NOE correlation between $\mathrm{H}_{2 \mathrm{ax}}$ and $\mathrm{H}_{14}$ and $\mathrm{H}_{15}$ methyls groups. Between the four possible conformations of germacrene moiety described by de Kraker et al., the only possibility is the conformation noted "UU" with the orientation of C-14 and C15 methyls groups to Upside [22]. The other NOE correlations observed between $\mathrm{H}_{1}-\mathrm{H}_{3 a x}, \mathrm{H}_{3 \mathrm{ax}}-\mathrm{H}_{5}, \mathrm{H}_{5}-\mathrm{H}_{7 \mathrm{ax}}, \mathrm{H}_{1}-\mathrm{H}_{5}$ give the stereochemistry of $\mathbf{1}$ (Fig. 3). Compound $\mathbf{1}$ was previously proposed by Zdero et al., as a possible intermediate compound in the transformation of germacrene $\mathrm{A}$ acid to the desacetyl derivative of compound 1, but it has never been isolated [19]. In our study, the structure of compound $\mathbf{1}$ isolated from I. montana is elucidated as shown, and this compound is called Eldarin.

Compound 2 (Fig. 2) was obtained as yellow oil. Its molecular formula $\mathrm{C}_{20} \mathrm{H}_{28} \mathrm{O}_{10}$ was established by positive HR-ESI-MS, which gave a pseudo-molecular 
ion peak at $\mathrm{m} / \mathrm{z} 429.1756[\mathrm{M}+\mathrm{H}]^{+}$(calcd. for $\mathrm{C}_{20} \mathrm{H}_{29} \mathrm{O}_{10}{ }^{+}$429.1755), with the existence of seven degrees of unsaturation. The IR spectrum suggested the presence of hydroxyl groups $\left(3472 \mathrm{~cm}^{-1}\right)$, carbonyl groups of ester function $(1751,1719$ and $\left.1222 \mathrm{~cm}^{-1}\right)$, double-bond groups $\left(3022,1647 \mathrm{~cm}^{-1}\right)$ and methyl groups $\left(1365 \mathrm{~cm}^{-1}\right)$. The ${ }^{1} \mathrm{H}$ and COSY NMR spectra indicated the presence of myoinositol structure with $\mathrm{H}-1$ axial at $5.02 \mathrm{ppm}(\mathrm{dd}, J 10.2,2.6 \mathrm{~Hz}), \mathrm{H}-2$ equatorial at $4.23 \mathrm{ppm}(\mathrm{t}, J 2.6 \mathrm{~Hz})$, H-3 axial at $3.84 \mathrm{ppm}(\mathrm{dd} J 10.0,2.6 \mathrm{~Hz}), \mathrm{H}-4$ axial at $5.44 \mathrm{ppm}(\mathrm{t}, J 10.0 \mathrm{~Hz}), \mathrm{H}-5$ axial at $5.26(\mathrm{t}, J 10.0 \mathrm{~Hz}$ ), and H-6 axial at $5.68 \mathrm{ppm}(\mathrm{t} J 10.0 \mathrm{~Hz})$. In the HMBC spectrum, the two ${ }^{1} \mathrm{H}$ resonances at 1.93 and $2.01 \mathrm{ppm}$ (each $3 \mathrm{H}, \mathrm{s}$ ) are correlated to two carbonyl carbons at 171.3 and at $172.0 \mathrm{ppm}$ respectively indicate two acetate moieties. Two other ${ }^{1} \mathrm{H}$ resonances at 1.92 and at $1.96 \mathrm{ppm}$ (each $3 \mathrm{H}$, dq $J 7.5,1.5$ ) correlated to each of two olifenic carbon at 128.4, $140.2 \mathrm{ppm}$ and at 128.6, 140.4 ppm respectively, and the two last ${ }^{1} \mathrm{H}$ resonances at 1.80 and 1.86 (each $3 \mathrm{H}$, br quint $J 1.5)$ correlated to each of two same olifenic carbons respectively, which indicated the presence of two angelate moieties. The four chemical shifts downfield at 5.02 ppm (H-1), 5.26 ppm (H-5), 5.44 ppm (H-4) and at 5.68 ppm (H-6) were connected to two acetate moieties with H-4 and H-6 respectively by the presence of HMBC (Fig. 3) correlation with carbonyl carbons at 172.0 and $171.3 \mathrm{ppm}$ respectively, and were connected to two angeloyl moieties with $\mathrm{H}-1$ and $\mathrm{H}-5$ by the presence of HMBC correlation with carbonyl carbons at 168.3 and 168.0 ppm respectively. The NOE correlations (Fig. 3) between H-1, H-5 with the methyl groups of angeloyl and H-4, H-6 with the methyl group of acetyl confirmed the structure of compound 2 as myoinositol-1,5-diangelate-4,6-diacetate.

Compound 3 (Fig. 2) was obtained as yellow oil. Its molecular formula $\mathrm{C}_{20} \mathrm{H}_{28} \mathrm{O}_{10}$ was established by positive HR-ESI-MS, which gave a pseudo-molecular ion peak at $\mathrm{m} / \mathrm{z} 429.1750[\mathrm{M}+\mathrm{H}]^{+}$(calcd. for $\mathrm{C}_{20} \mathrm{H}_{29} \mathrm{O}_{10}{ }^{+} 429.1755$ ), with the existence of seven degrees of unsaturation. The IR, ${ }^{1} \mathrm{H}$ and ${ }^{13} \mathrm{C}$ NMR spectra are close to compound 2 with the presence of two angeloyl, two acetate moieties and one myoinositol structure. The main difference observed is a substituent pattern of inositol ring: the HMBC spectrum (Fig. 3) showed that H-5 at $5.22 \mathrm{ppm}(\mathrm{t}, J 10.0)$ is connected with an acetate carbonyl at $171.2 \mathrm{ppm}$, and H-6 at $5.73 \mathrm{ppm}(\mathrm{t}, J 10.0)$ is 
connected with an angeloyl carbonyl at $167.7 \mathrm{ppm}$. Thus, compound $\mathbf{3}$ was established as myoinositol-1,6-diangelate-4,5-diacetate.

Compound 4 (Fig. 1) has been obtained as a mix with compound 5 as yellow oil. The molecular formula $\mathrm{C}_{20} \mathrm{H}_{30} \mathrm{O}_{10}$ was established by positive HR-ESI-MS , which gave a pseudo-molecular ion peak at $\mathrm{m} / \mathrm{z} 431.1908[\mathrm{M}+\mathrm{H}]^{+}$(calcd. for $\mathrm{C}_{20} \mathrm{H}_{31} \mathrm{O}_{10}{ }^{+} 431.1912$ ), with an existence of six degrees of unsaturation. The IR, ${ }^{1} \mathrm{H}$ and ${ }^{13} \mathrm{C}$ NMR spectra are close to compound 3 with an exception for compound 4 with the presence of a hydrogenated double bond of one angeloyl moiety. The ${ }^{1} \mathrm{H}$ NMR spectrum showed two methyl resonances at $0.83 \mathrm{ppm}(\mathrm{t}, J 7.4), 1.03 \mathrm{ppm}(\mathrm{d}, J$ 7.0), one methylene with two resonances at $1.58 \mathrm{ppm}(\mathrm{m}), 1.38 \mathrm{ppm}(\mathrm{m})$ and one methine resonance at $2.29 \mathrm{ppm}(\mathrm{m})$ linked to carbonyl ester at $176.5 \mathrm{ppm}$ corresponding to the 2-methylbutiroyl moiety. The HMBC spectrum (Fig. 3) showed that H-6 at $5.65 \mathrm{ppm}(\mathrm{t}, J$ 10.0) is connected with the 2-methylbutiroyl carbonyl at 176.5 ppm, thus, compound 4 was established as myoinositol-1-angelate-4,5diacetate-6-(2-methylbutirate).

For compound 5, the ${ }^{1} \mathrm{H}$ NMR spectrum showed the second difference with the spectrum of compound $\mathbf{3}$ with two methyl resonances at $0.89 \mathrm{ppm}$ (each $\mathrm{d}, J 6.7$ ), one methylene with two resonances at $2.12 \mathrm{ppm}(\mathrm{dd}, J$ 14.9, 7.4), $2.09 \mathrm{ppm}$ (dd, $J$ 14.9, 6.8) and one methine resonance at $1.96 \mathrm{ppm}(\mathrm{m})$ linked to carbonyl ester at 172.9 ppm corresponding of an isovaleroyl moiety. The HMBC spectrum (Fig. 3) showed that $\mathrm{H}-6$ at $5.65 \mathrm{ppm}(\mathrm{t}, 10.0)$ is connected with the isovaleroyl carbonyl at 172.9 ppm, thus, compound 5 was established as myoinositol-1-angelate-4,5-diacetate-6isovalerate. 


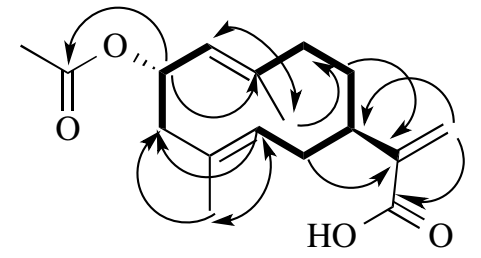

1

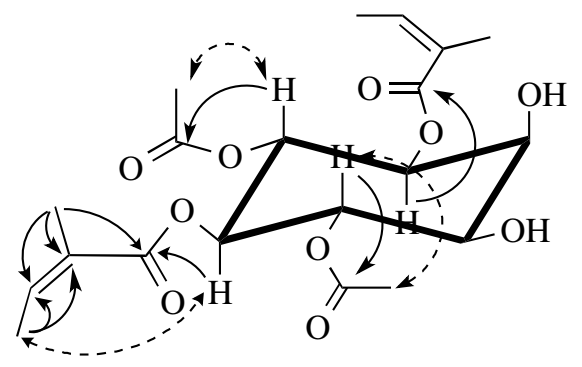

2

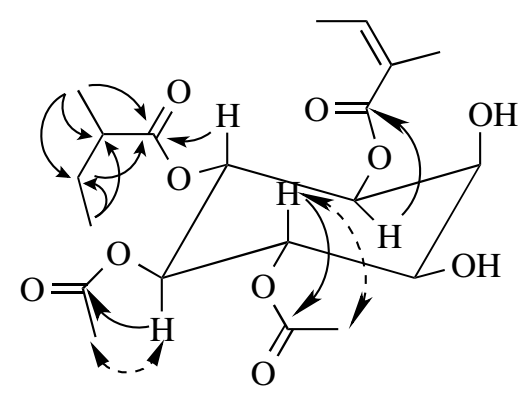

4

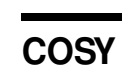

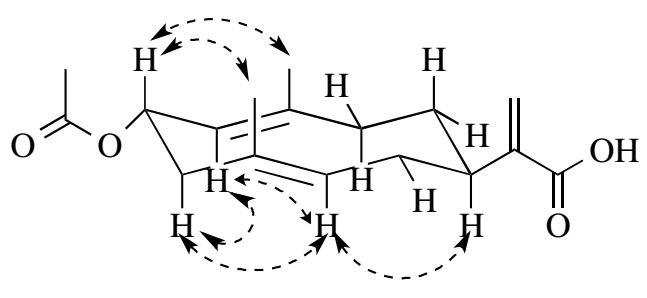

1

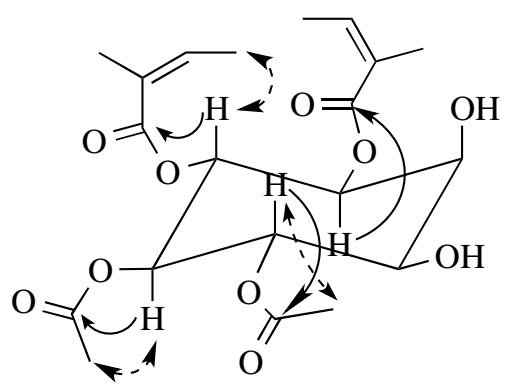

3

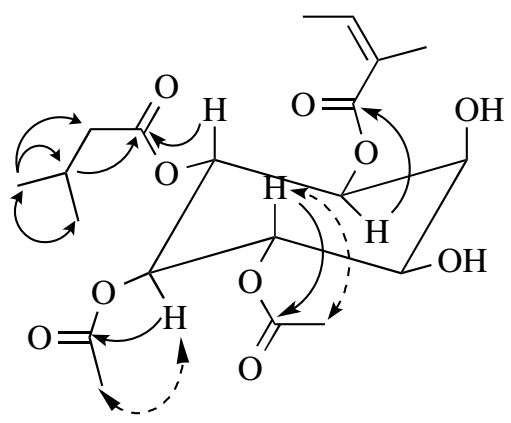

5

NOE

Fig. 3. Keys COSY, HMBC and NOE correlations of compounds 1 - 5.

Anti-inflammatory activity and cytotoxicity of nine isolated compounds have been tested in vitro comparing to dexamethasone as a positive control. The results are summarized in Table 4. The new inositol derivatives $\mathbf{2}$ and $\mathbf{3}$, sesquiterpene lactones 7, 13 and 15 and phenolic compounds 14 and 16 showed release of NO with $\mathrm{IC}_{50}$ value $<30 \mu \mathrm{M}$ on macrophages RAW 264.7, while compounds 1 and $\mathbf{1 2}$ have not shown neither anti-inflammatory activity, nor cytotoxicity at the concentrations at 51.34 and $22.04 \mu \mathrm{M}$ respectively. Compound $\mathbf{1 5}$ exhibited cytotoxicity with $\mathrm{IC}_{50}$ value $1.21 \mu \mathrm{M}$. Comparing the anti-inflammatory ratio we can conclude that compounds $2,7,13,14$ and 16 present promised anti-inflammatory activity with the anti-inflammatory ratio higher than the positive control dexamethasone. 
Anti-inflammatory, cytotoxic activity and anti-inflammatory ratio of compounds 1-3, 7, 12-16.

\begin{tabular}{|c|c|c|c|}
\hline Compounds & $\begin{array}{l}\text { NO release } \\
\mathrm{IC}_{50}(\mu \mathrm{M})^{\mathrm{a}}\end{array}$ & $\begin{array}{c}\text { Toxicity } \\
\text { IC }_{50}(\mu \mathrm{M})\end{array}$ & $\begin{array}{c}\text { Anti-inflammatory } \\
\text { ratio }\end{array}$ \\
\hline $\mathbf{1}$ & $>51.34$ & $>51.34$ & - \\
\hline 2 & $3.53 \pm 0.97$ & $213.93 \pm 24.5$ & 60 \\
\hline 3 & $27.37 \pm 6.7$ & $144.1 \pm 13.7$ & 5 \\
\hline 7 & $0.16 \pm 0.07$ & $18.93 \pm 3.1$ & 126 \\
\hline 12 & $>22.04$ & $>22.04$ & - \\
\hline 13 & $0.3 \pm 0.07$ & $17.78 \pm 1.4$ & 59 \\
\hline 14 & $1.63 \pm 0.55$ & $178.08 \pm 24.1$ & 109 \\
\hline 15 & $0.68 \pm 0.09$ & $1.21 \pm 0.14$ & 2 \\
\hline 16 & $0.4 \pm 0.08$ & $22.98 \pm 5.7$ & 57 \\
\hline Dexamethasone ${ }^{b}$ & 4.33 & 163.33 & 38 \\
\hline
\end{tabular}

\section{Acknowledgements}

The work was supported by the region PACA (France) (grant number 201308504), the Embassy of France in Azerbaijan and the Luberon Natural Regional Park in France.

We are grateful to Mr. Vincent Lorenzini from the Embassy of France in Azerbaijan for his contribution on funding of this research project work, to Dr. Valérie Monnier, to Dr. Jean-Valère Naubron and Dr. Christophe Chendo from Spectropole laboratory (France) for the spectroscopic analysis and to Dr. Didier Morisot and Mr. Laurent Michel for their botanical identification.

\section{Conflict of Interest Statement}

The authors have declared that there is no conflict of interest. 


\section{References}

[1] Y.-M. Zhao, M.-L. Zhang, Q.-W. Shi, H. Kiyota, Chemical constituents of plants from the genus Inula, Chem. Biodivers. 3 (2006) 371-384.

[2] A.M.L. Seca, A. Grigore, D.C.G.A. Pinto, A.M.S. Silva, The genus Inula and their metabolites: From ethnopharmacological to medicinal uses, J. Ethnopharmacol. 154 (2014) 286-310. doi:10.1016/j.jep.2014.04.010.

[3] J. Wu, C. Tang, S. Yao, L. Zhang, C. Ke, L. Feng, G. Lin, Y. Ye, Antiinflammatory Inositol Derivatives from the Whole Plant of Inula cappa, J. Nat. Prod. 78 (2015) 2332-2338. doi:10.1021/acs.jnatprod.5b00135.

[4] Amir, Les cueillettes de confiance, édition Forcalquier, 1998.

[5] Gonzalez Romero M.A., Villaescusa Castillo L., Diaz Lanza A.M., Bartolome Esteban C., Fernandez Matellano L., Phytochemistry and pharmacological studies of Inula montana, Recent Res. Dev. Phytochem. 5 (2001) 255-268.

[6] J. Reynaud, M. Lussignol, Note Free Flavonoid Aglycones from Inula montana, Pharm. Biol. 37 (1999) 163-164. doi:10.1076/phbi.37.2.163.6079.

[7] Nabila Belyagoubi-Benhammou, L. Belyagoubi, Fawzia Atik Bekkara,

Phenolic contents and antioxidant activities in vitro of some selected Algerian plants, J. Med. Plant Res. 8 (2014) 1198-1207.

[8] T. Martín, L. Villaescusa, M. Gasquet, F. Delmas, C. Bartolomé, A.M. DíazLanza, E. Ollivier, G. Balansard, Screening for Protozoocidal Activity of Spanish Plants, Pharm. Biol. 36 (1998) 56-62. doi:10.1076/phbi.36.1.56.4627.

[9] C. Wang, X. Zhang, P. Wei, X. Cheng, J. Ren, S. Yan, W. Zhang, H. Jin, Chemical constituents from Inula wissmanniana and their anti-inflammatory activities, Arch. Pharm. Res. 36 (2013) 1516-1524. doi:10.1007/s12272-013-0143-1. [10] A.M. Clark, C.D. Hufford, Microbial transformations of the sesquiterpene lactone costunolide, J. Chem. Soc. [Perkin 1]. (1979) 3022. doi:10.1039/p19790003022.

[11] T.A. Geissman, Sesquiterpene lactones of Artemisia-A. verlotorum and A. vulgaris, Phytochemistry. 9 (1970) 2377-2381.

[12] A.J.R. da Silva, M. Garcia, P.M. Baker, J.A. Rabi, 13C NMR spectra of natural products. 2-eudesmanolides, Org. Magn. Reson. 16 (1981) 234-235. doi: $10.1002 / \mathrm{mrc} .1270160314$.

[13] D.T. Huong, C. Kamperdick, T.V. Sung, Homogentisic Acid Derivatives from Miliusa balansae, J. Nat. Prod. 67 (2004) 445-447. doi:10.1021/np030195z.

[14] L. Bailian, Chemical constituents of Laggera pterodonta, China J. Chin. Matera Medica. 35 (2010). doi:10.4268/cjcmm20100513.

[15] H. Yoshioka, W. Renold, N.H. Fischer, A. Higo, T.J. Mabry, Sesquiterpene lactones from Ambrosia confertiflora (Compositae), Phytochemistry. 9 (1970) 823832. doi:10.1016/S0031-9422(00)85188-2.

[16] S. Öksüz, G. Topcu, Triterpene fatty acid esters and flavonoids from Inula britannica, Phytochemistry. 26 (1987) 3082-3084. doi:10.1016/S00319422(00)84603-8.

[17] K. Tori, I. Horibe, Y. Tamura, H. Tada, Simultaneous application of the nuclear Overhauser effect and an N.M.R. shift reagent. Conformation of costunolide and dihydrocostunolide in solution, J. Chem. Soc. Chem. Commun. (1973) 620. doi:10.1039/c39730000620. 
[18] R. Chang, C. Wang, Q. Zeng, B. Guan, W. Zhang, H. Jin, Chemical constituents of the stems of Celastrus rugosus, Arch. Pharm. Res. 36 (2013) 12911301. doi:10.1007/s12272-013-0145-z.

[19] F. Bohlmann, P.K. Mahanta, J. Jakupovic, R.C. Rastogi, A.A. Natu, New sesquiterpene lactones from Inula species, Phytochemistry. 17 (1978) 1165-1172. doi:10.1016/S0031-9422(00)94308-5.

[20] Z.-M. Zou, H.-G. Xie, H.-W. Zhang, L.-Z. Xu, Inositol angelates from the whole herb of Inula cappa, Fitoterapia. 79 (2008) 393-394.

doi:10.1016/j.fitote.2007.11.031.

[21] T. Nagao, F. Abe, J. Kinjo, H. Okabe, Antiproliferative Constituents in Plants 10. Flavones from the Leaves of Lantana montevidensis BRIQ. and Consideration of Structure-Activity Relationship, Biol. Pharm. Bull. 25 (2002) 875-879. doi:10.1248/bpb.25.875.

[22] J.-W. de Kraker, M.C. Franssen, A. de Groot, T. Shibata, H.J. Bouwmeester, Germacrenes from fresh costus roots, Phytochemistry. 58 (2001) 481-487. 


\section{New sesquiterpene acid and inositol derivatives from Inula montana $\mathrm{L}$.}

Elnur Garayev ${ }^{1}$, Gaëtan Herbette $^{2}$, Carole Di Giorgio ${ }^{3}$, Philippe

Chiffolleau ${ }^{4}$, David Roux ${ }^{5}$, Huguette Sallanon ${ }^{5}$, Evelyne Ollivier ${ }^{1}$, Riad Elias $^{1}$, Béatrice Baghdikian ${ }^{1 *}$

${ }^{1}$ Aix Marseille Univ, UMR-MD3, Laboratory of Pharmacognosy and Ethnopharmacology, Faculty of Pharmacy, 27 bld Jean Moulin - CS 30064, 13385 Marseille, France

${ }^{2}$ Aix Marseille Univ, Spectropole, FR1739, Service 511, Campus SaintJérome, 13397 Marseille, France.

${ }^{3}$ Aix Marseille Univ, Laboratoire de Mutagenèse Environnementale, IMBE, IFR ECCOREV, Faculty of Pharmacy, 27 bld Jean Moulin- CS 30064, 13385 Marseille, France

${ }^{4}$ Luberon Natural Regional Park, 60, place Jean Jaurès, 84400 Apt, France ${ }^{5}$ Avignon University, Qualisud, UMR 95, F-84000, Avignon, France

\section{Supporting Information}

*Corresponding author: beatrice.baghdikian@univ-amu.fr

Index

For Compound 1: 
S1. ${ }^{1} \mathrm{H}$ NMR Spectrum (600 MHz, $\mathrm{CDCl}_{3}$ ) of Compound 1

S2. ${ }^{13} \mathrm{C}$ NMR Spectrum $\left(150 \mathrm{MHz}, \mathrm{CDCl}_{3}\right)$ of Compound $\mathbf{1}$

S3. HSQC Spectrum of Compound 1

S4. ${ }^{1} \mathrm{H}-{ }^{1} \mathrm{H}$ COSY Spectrum of Compound 1

S5. NOESY Spectrum of Compound 1

S6. IR Spectrum of Compound 1

S7. HR-ESI-MS Spectrum of Compound 1

\section{For Compound 2:}

S8. ${ }^{1} \mathrm{H}$ NMR Spectrum (600 MHz, $\left.\mathrm{CD}_{3} \mathrm{OD}\right)$ of Compound 2

S9. DEPTQ135 Spectrum of Compound 2

S10. HSQC Spectrum of Compound 2

S11. HMBC Spectrum of Compound 2

S12. ${ }^{1} \mathrm{H}-{ }^{1} \mathrm{H}$ COSY Spectrum of Compound 2

S13. NOESY Spectrum of Compound 2

S14. IR Spectrum of Compound 2

S15. HR-ESI-MS Spectrum of Compound 2

\section{For Compound 3:}

S16. ${ }^{1} \mathrm{H}$ NMR Spectrum (600 MHz, $\mathrm{CD}_{3} \mathrm{OD}$ ) of Compound 3

S17. ${ }^{13} \mathrm{C}$ NMR Spectrum (150 MHz, $\mathrm{CD}_{3} \mathrm{OD}$ ) of Compound 3

S18. HMBC Spectrum of Compound 3

S19. ${ }^{1} \mathrm{H}-{ }^{1} \mathrm{H}$ COSY Spectrum of Compound 3

S20. NOESY Spectrum of Compound 3

S21. IR Spectrum of Compound 3

S22. HR-ESI-MS Spectrum of Compound 3

\section{For mix of Compound 4 and Compound 5:}

S23. ${ }^{1} \mathrm{H}$ NMR Spectrum (600 MHz, $\mathrm{CD}_{3} \mathrm{OD}$ ) of mix of Compound 4 and Compound 5

S24. DEPTQ135 Spectrum of mix of Compound 4 and Compound 5

S25. HSQC Spectrum of mix of Compound $\mathbf{4}$ and Compound 5

S26. HMBC Spectrum of mix of Compound 4 and Compound 5

S27. ${ }^{1} \mathrm{H}_{-}{ }^{1} \mathrm{H}$ COSY Spectrum of mix of Compound $\mathbf{4}$ and Compound 5

S28. NOESY Spectrum of mix of Compound $\mathbf{4}$ and Compound 5

S29. IR Spectrum of mix of Compound 4 and Compound 5

S30. HR-ESI-MS Spectrum of mix of Compound $\mathbf{4}$ and Compound 5 
For Compound 1:

S1. ${ }^{1} \mathrm{H}$ NMR Spectrum (600 $\left.\mathrm{MHz}, \mathrm{CDCl}_{3}\right)$ of Compound 1

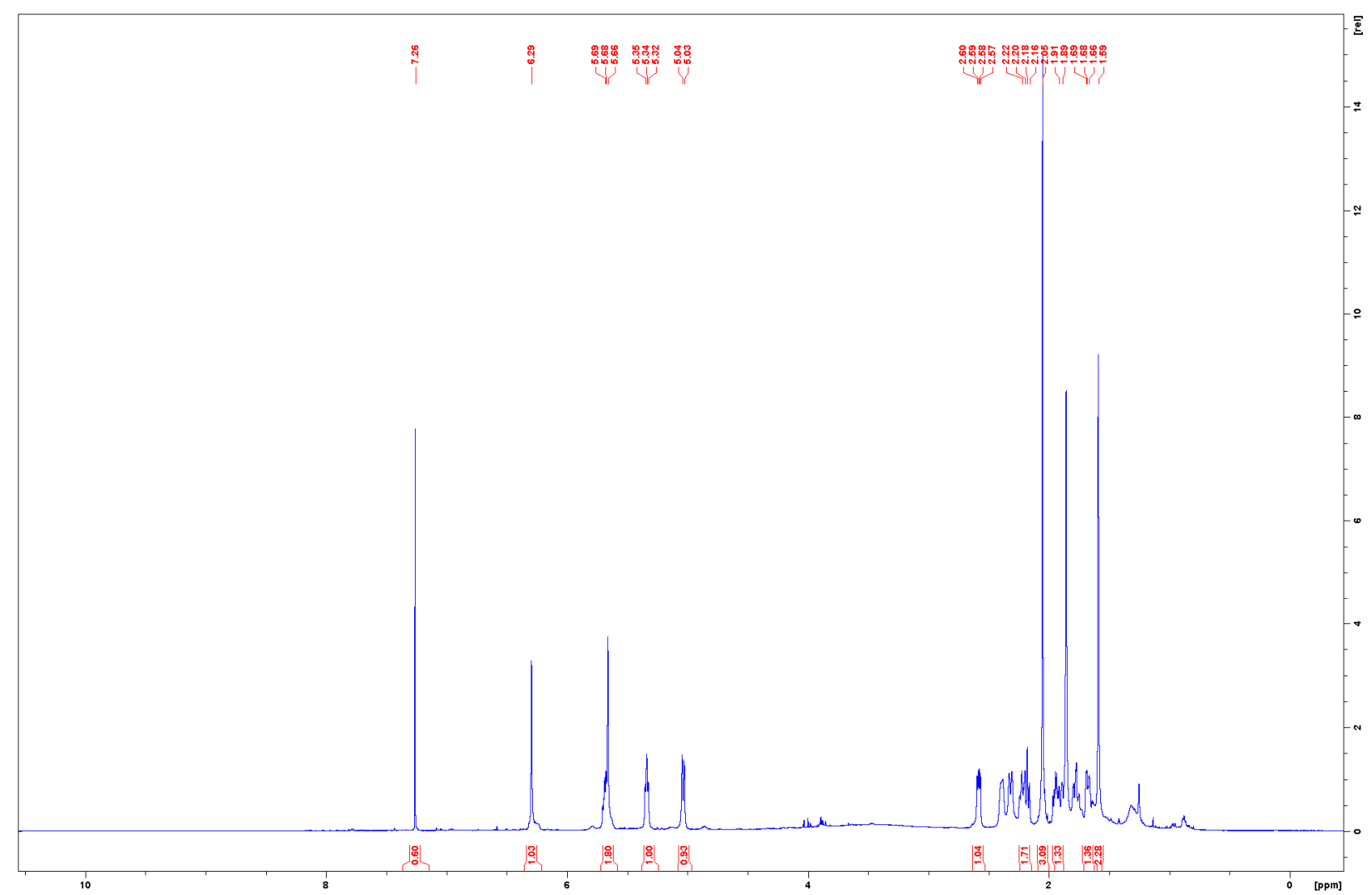

S2. ${ }^{13} \mathrm{C}$ NMR Spectrum (150 MHz, $\left.\mathrm{CDCl}_{3}\right)$ of Compound 1

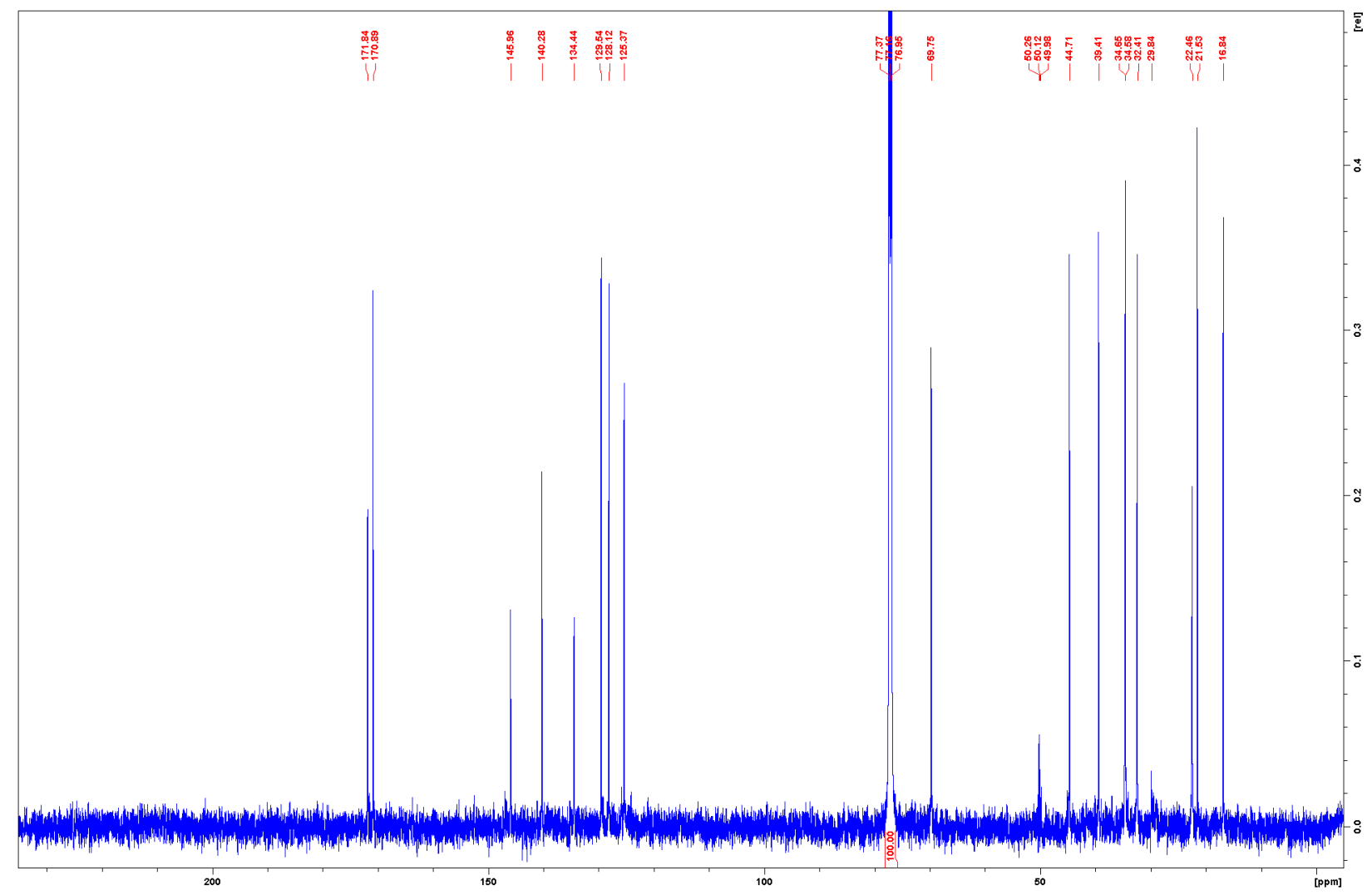


S3. HSQC Spectrum of Compound 1

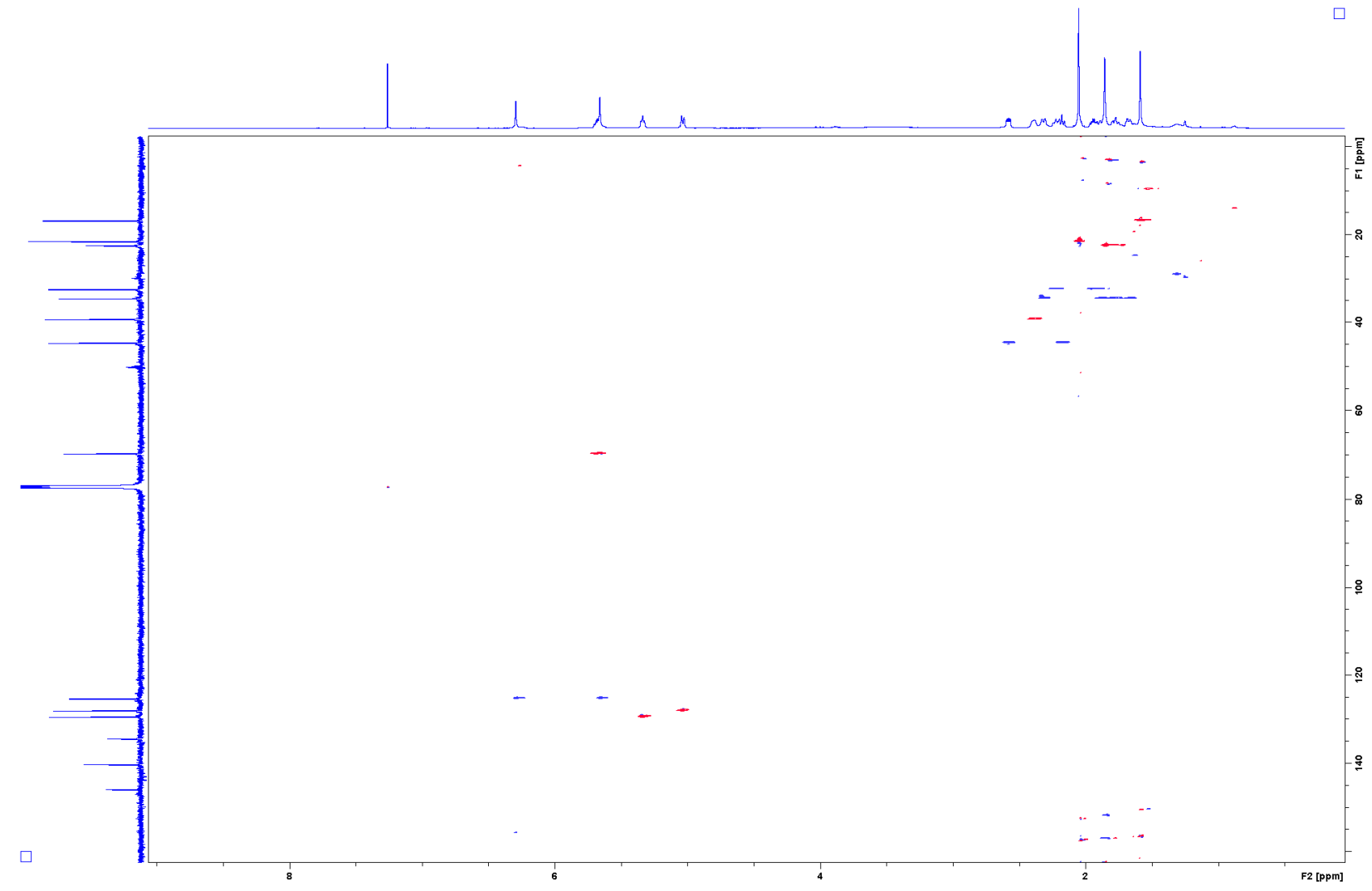

S4. HMBC Spectrum of Compound 1

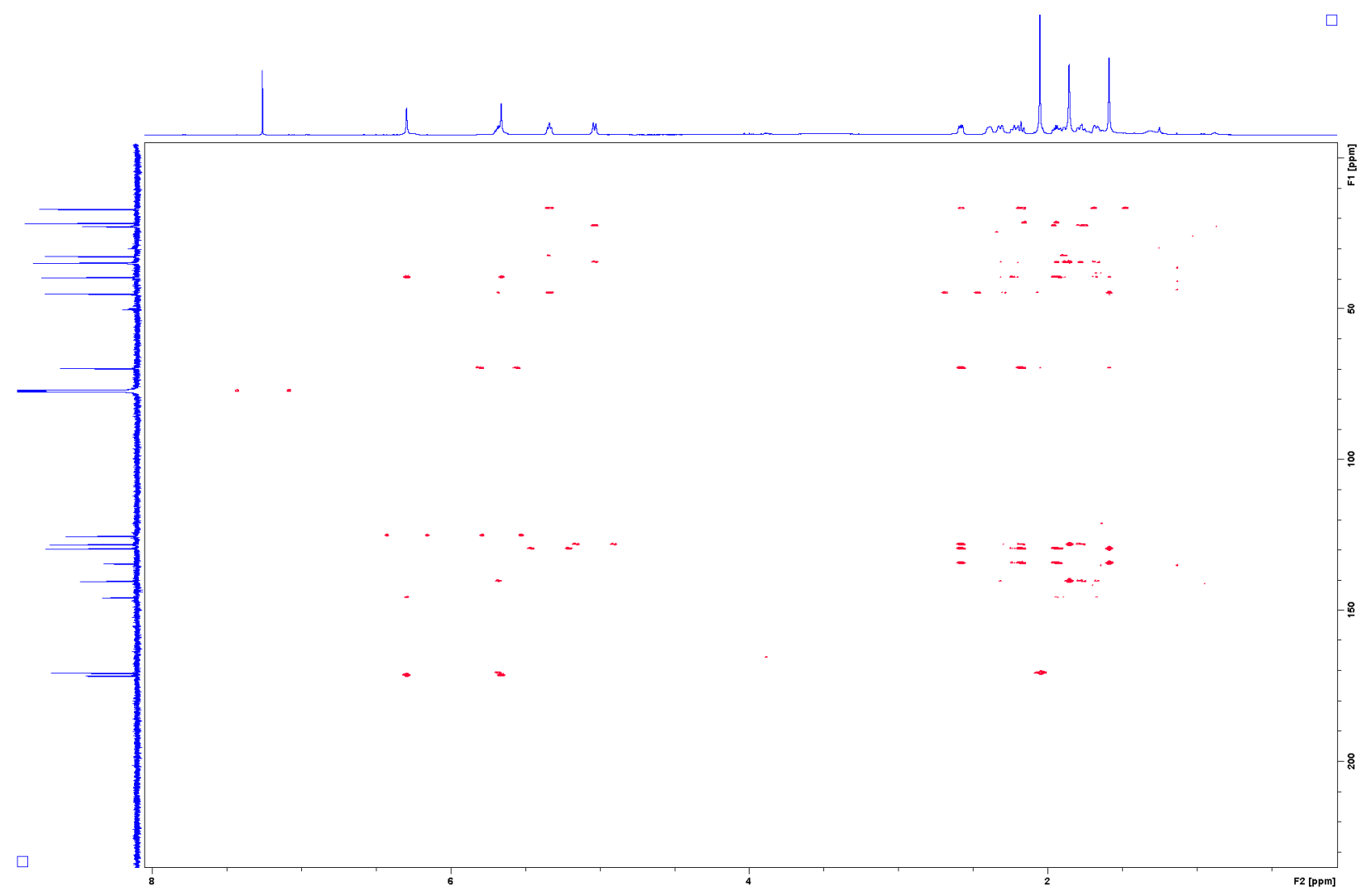


S4. ${ }^{1} \mathrm{H}-{ }^{1} \mathrm{H}$ COSY Spectrum of Compound 1

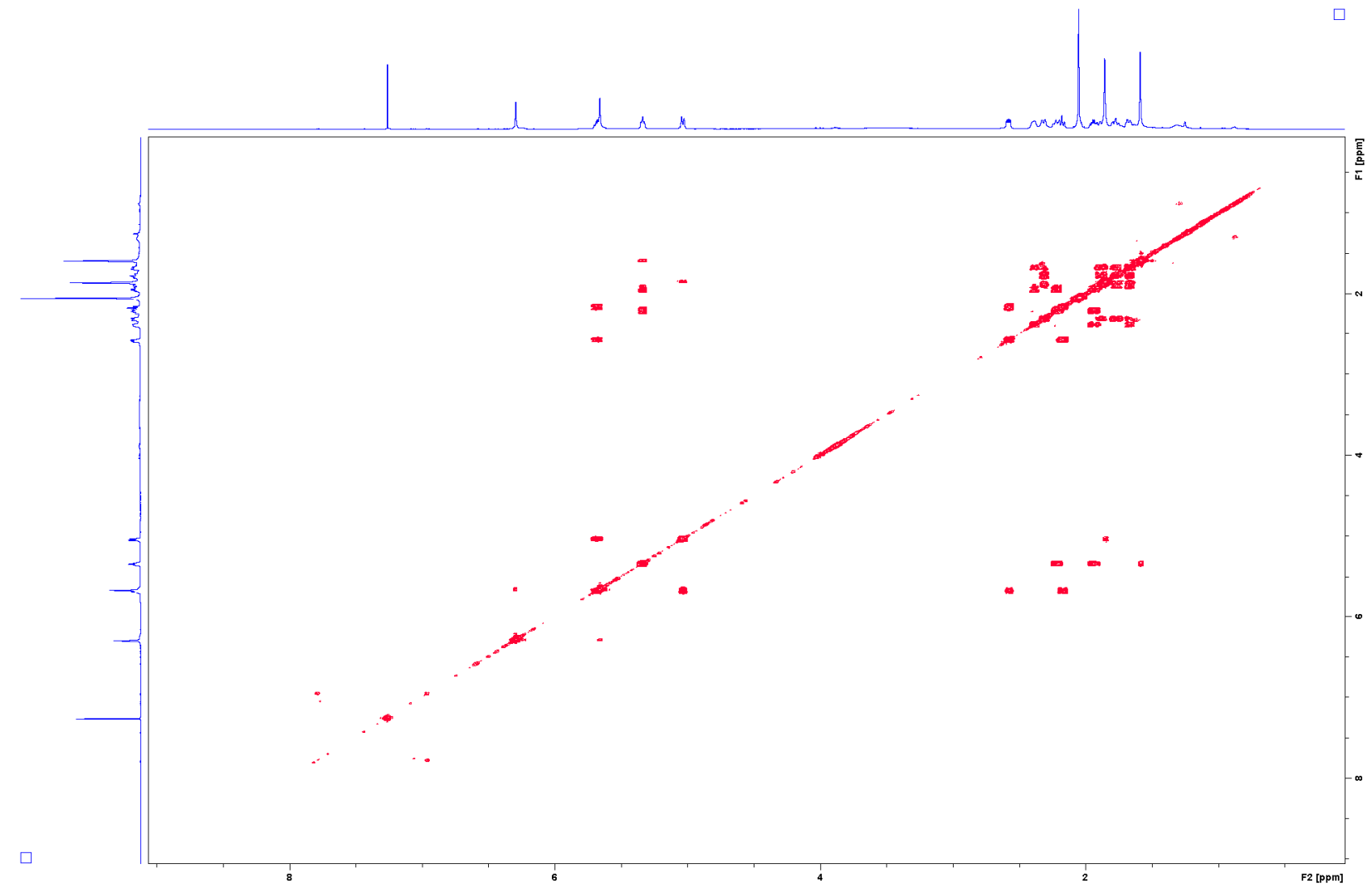

S5. NOESY Spectrum of Compound 1

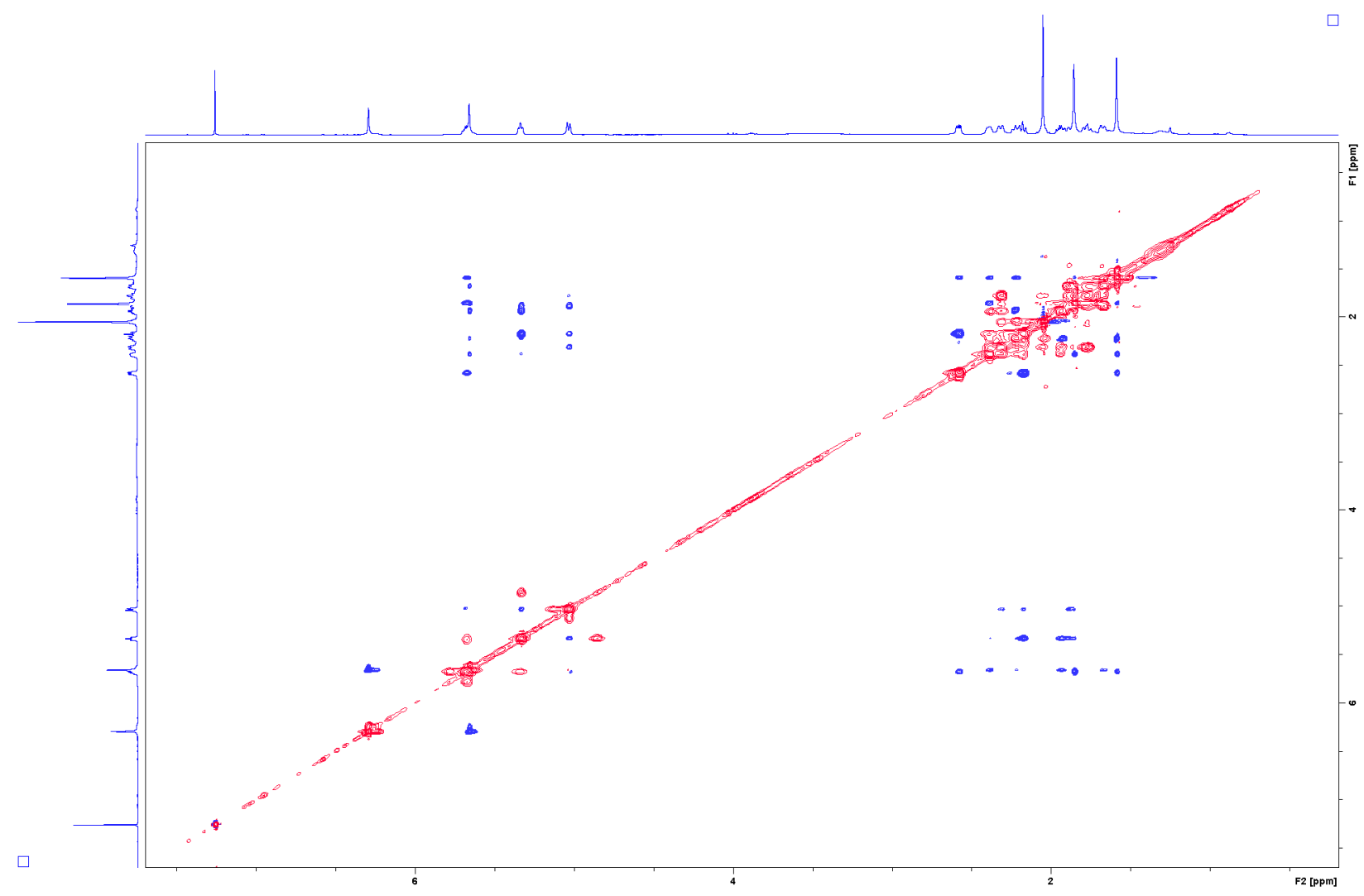


S6. IR Spectrum of Compound 1

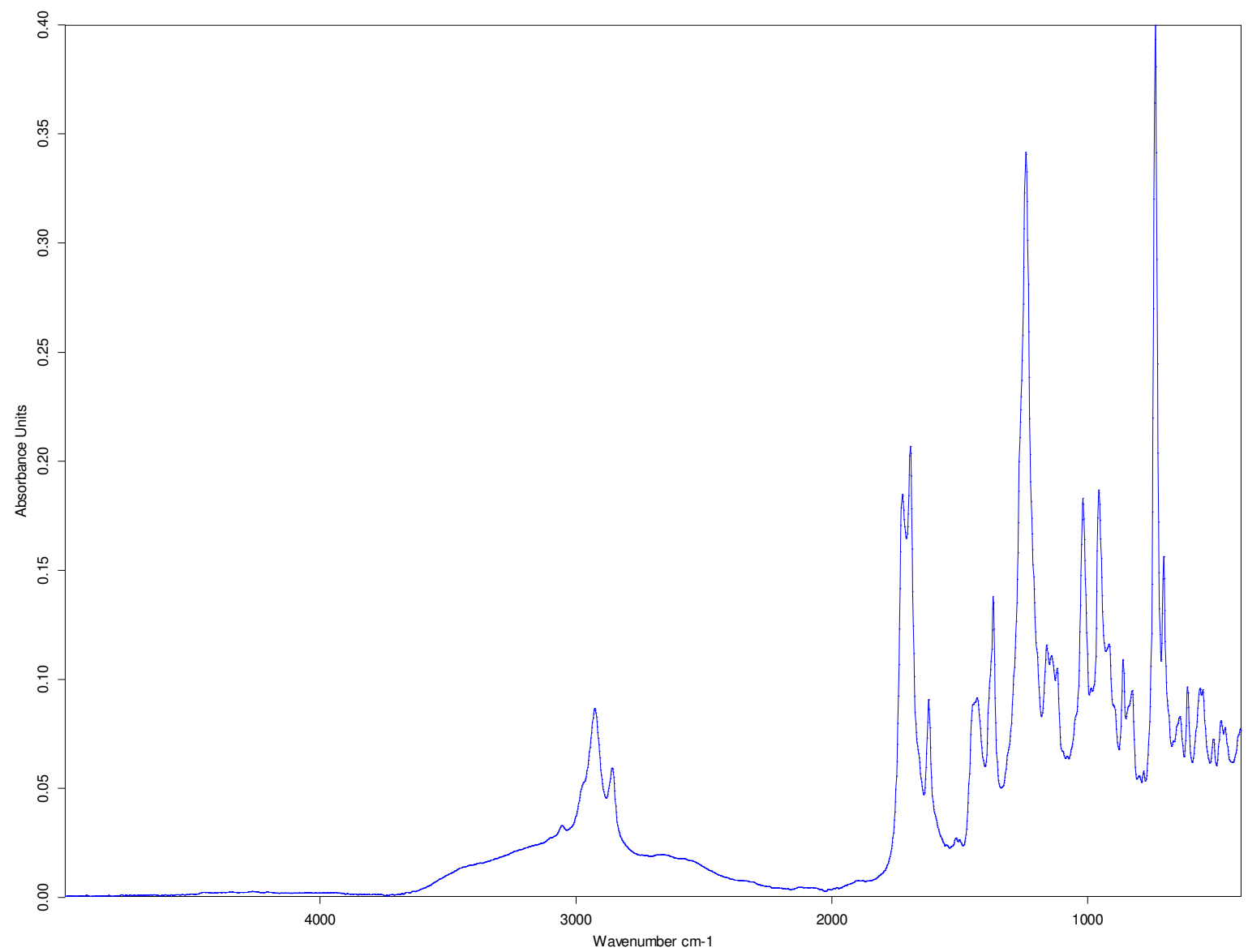

\section{S7. HR-ESI-MS Spectrum of Compound 1}

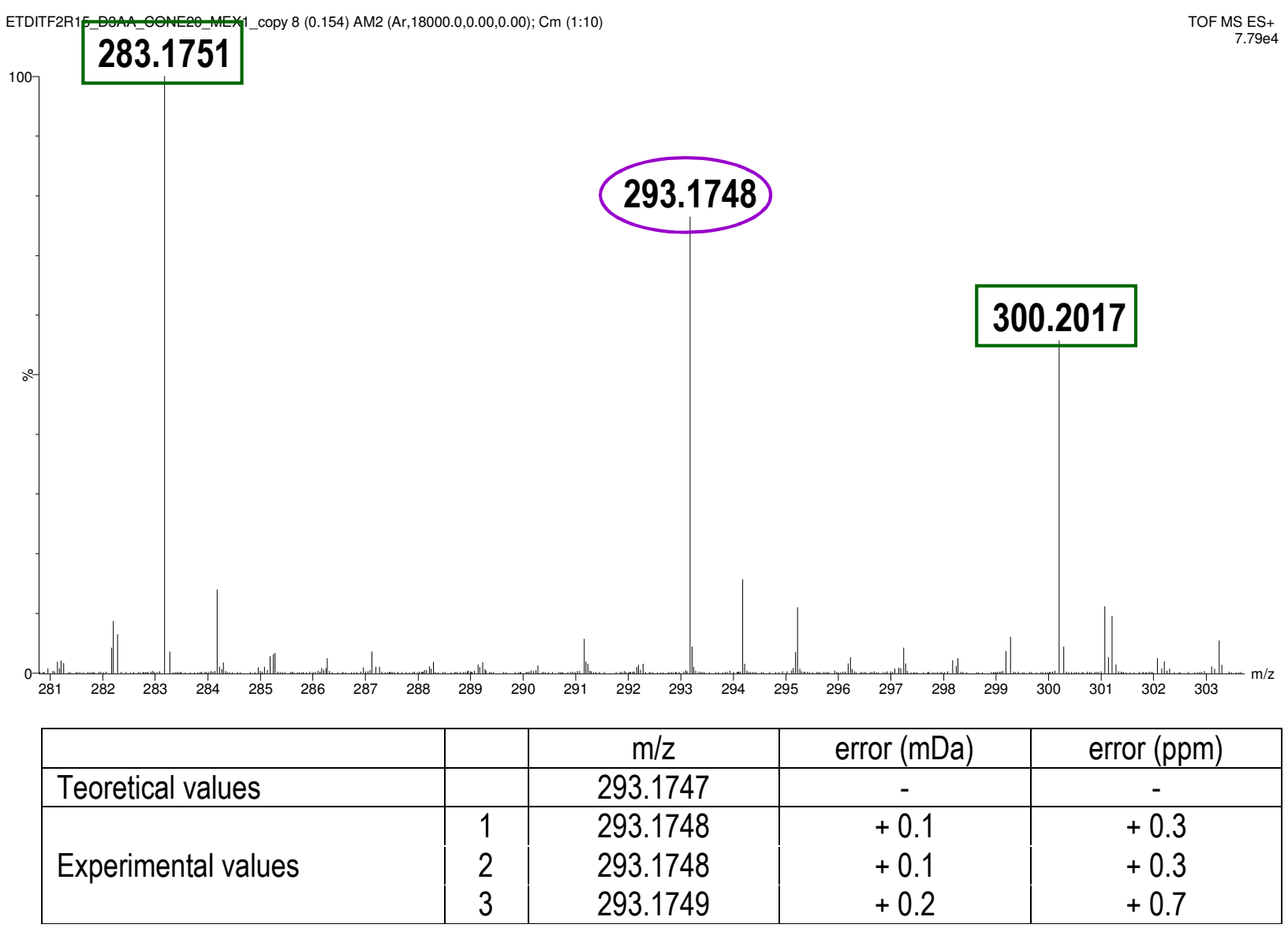

For Compound 2: 
S8. ${ }^{1} \mathrm{H}$ NMR Spectrum (600 $\left.\mathrm{MHz}, \mathrm{CD}_{3} \mathrm{OD}\right)$ of Compound 2

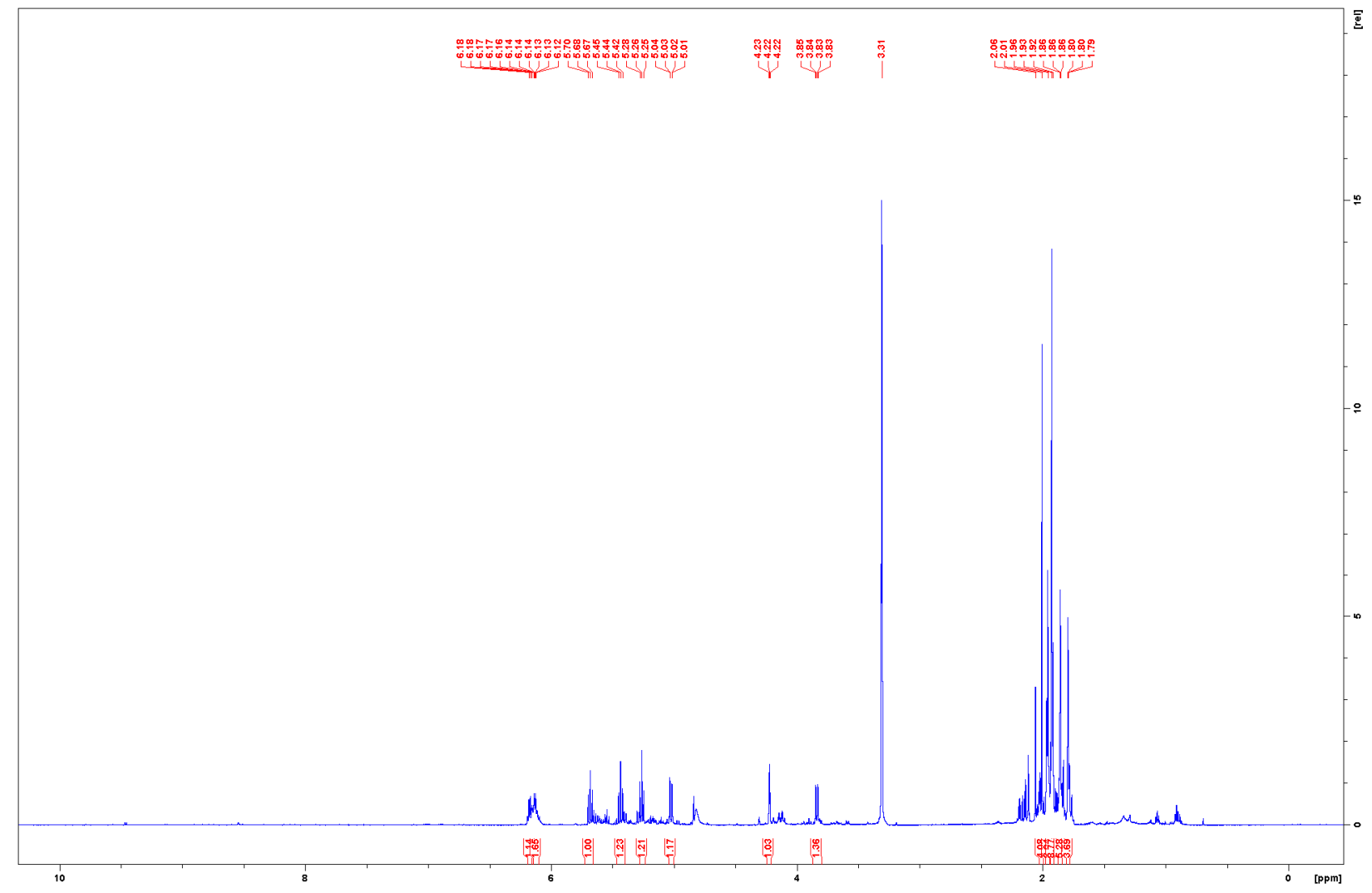

S9. DEPTQ135 Spectrum of Compound 2

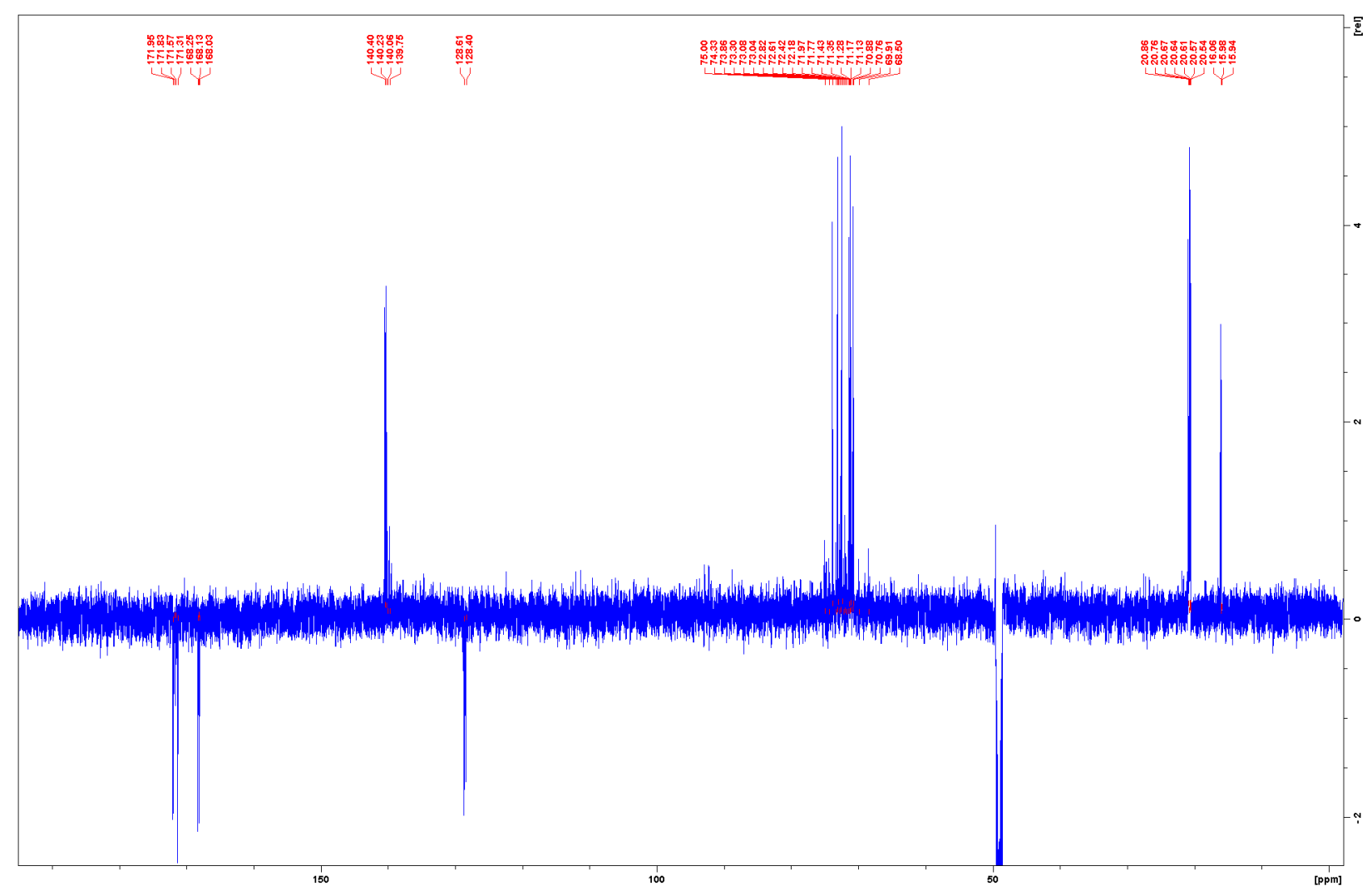


S10. HSQC Spectrum of Compound 2

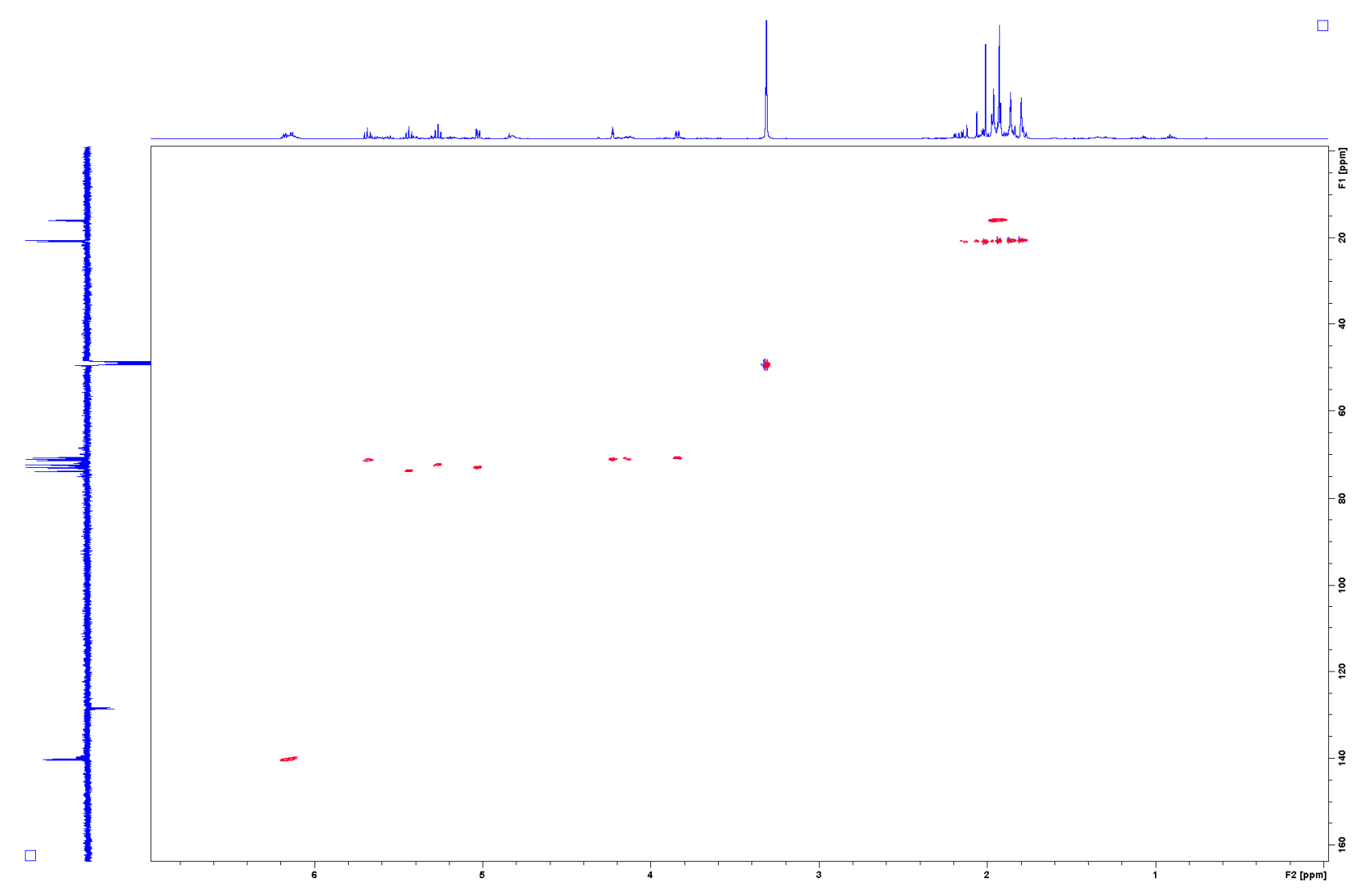

S11. HMBC Spectrum of Compound 2

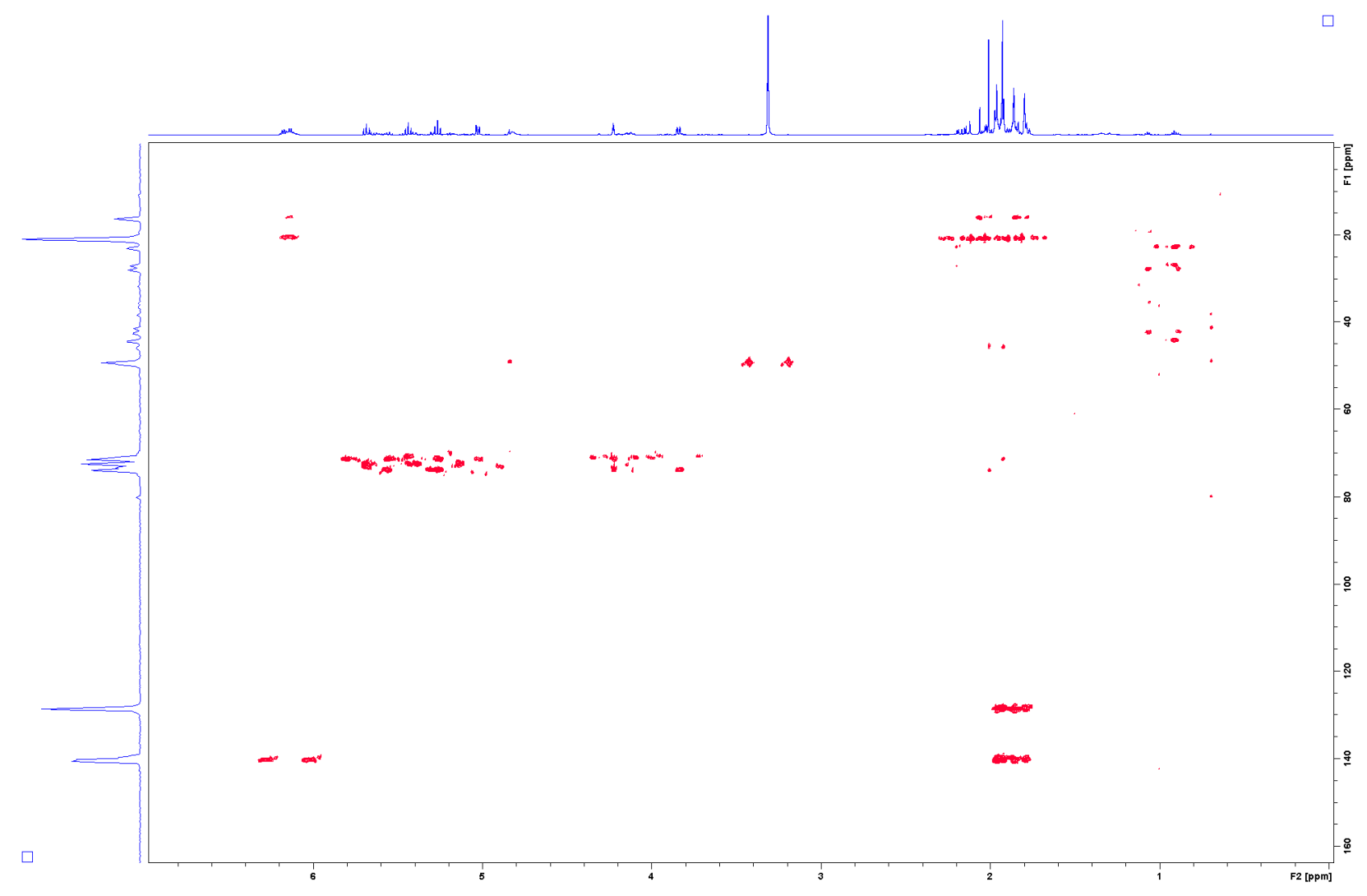

25 
S12. ${ }^{1} \mathrm{H}-{ }^{1} \mathrm{H}$ COSY Spectrum of Compound 2

$\square$

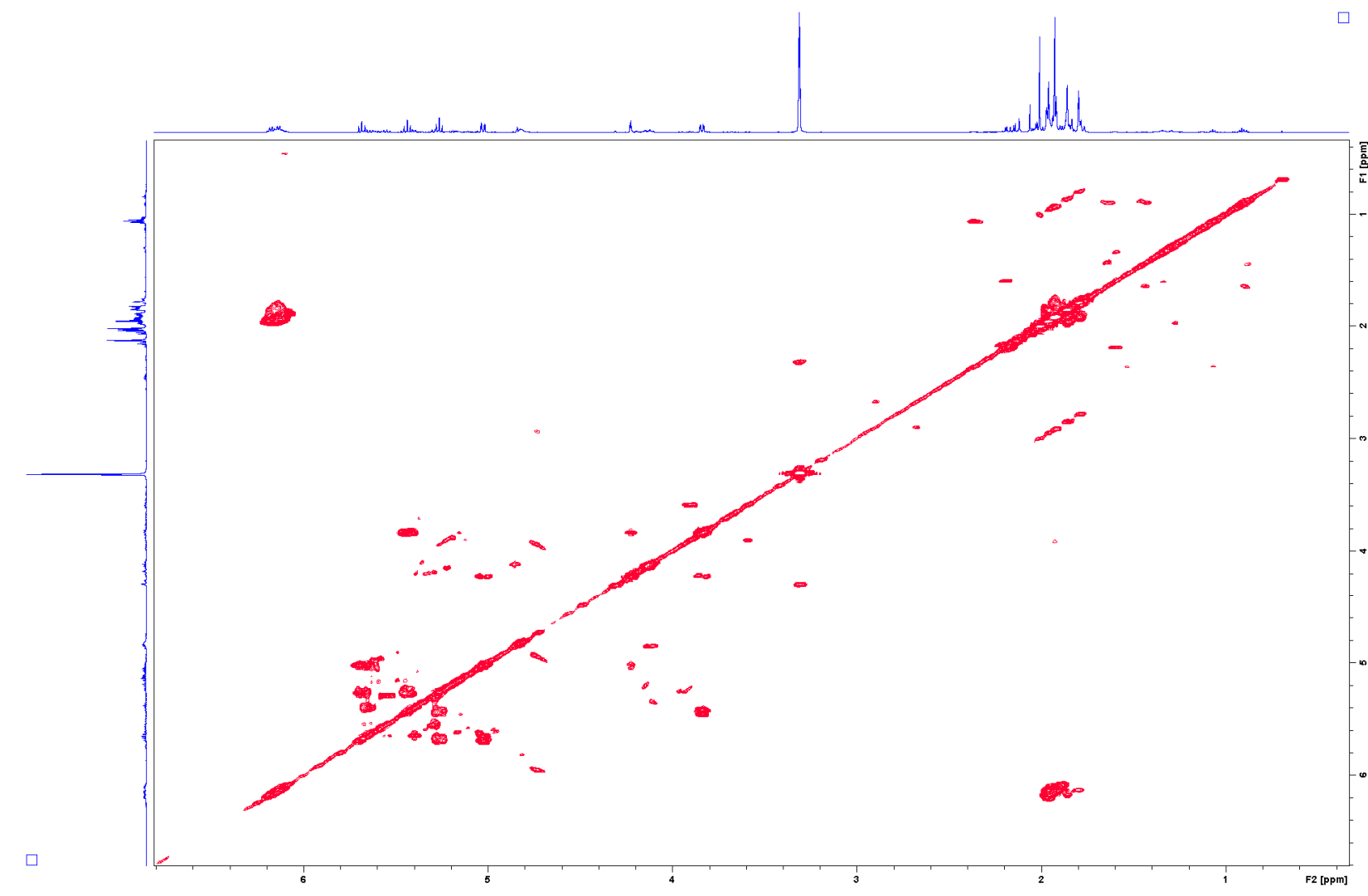

S13. NOESY Spectrum of Compound 2

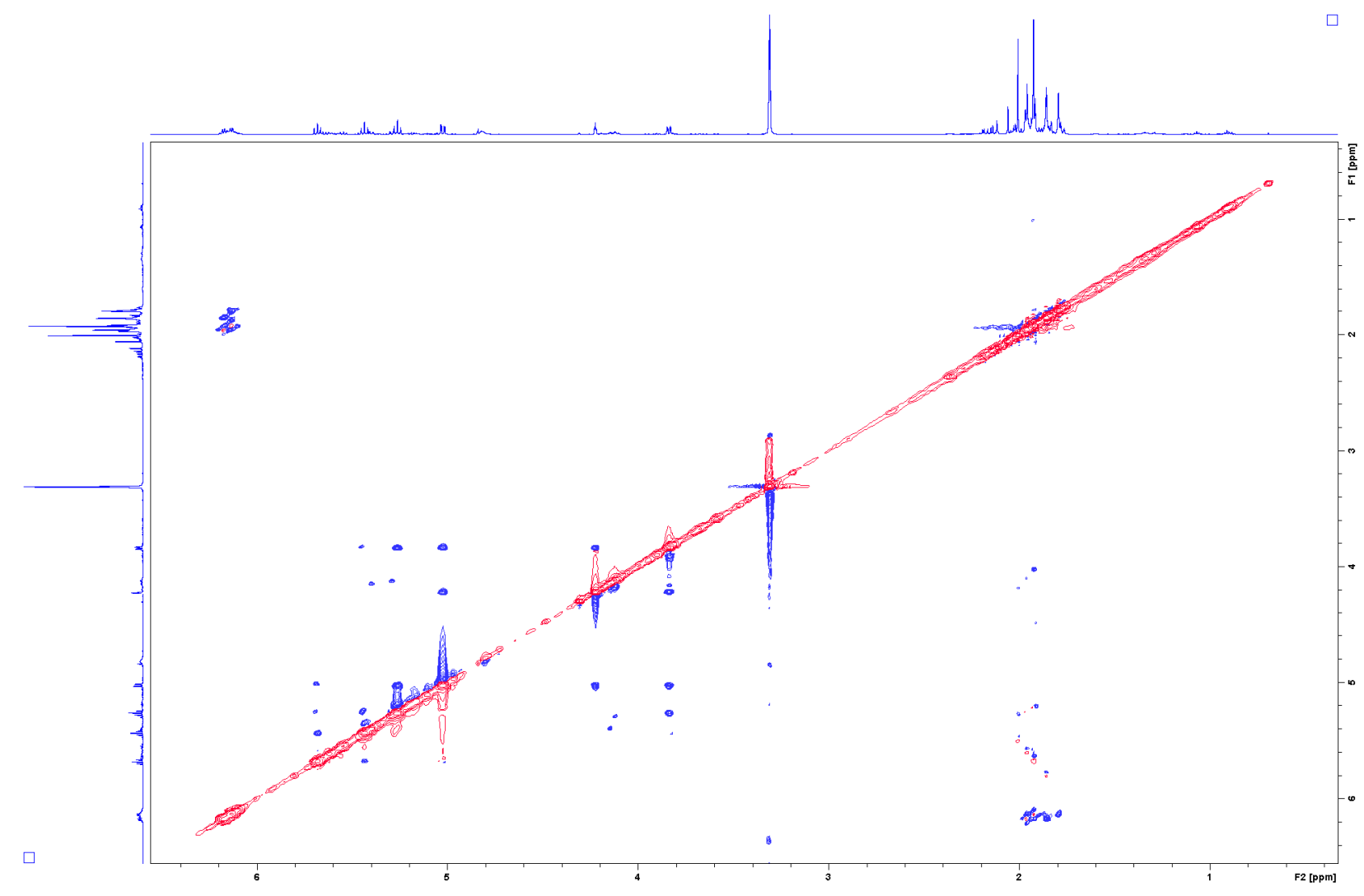

26 
S14. IR Spectrum of Compound 2

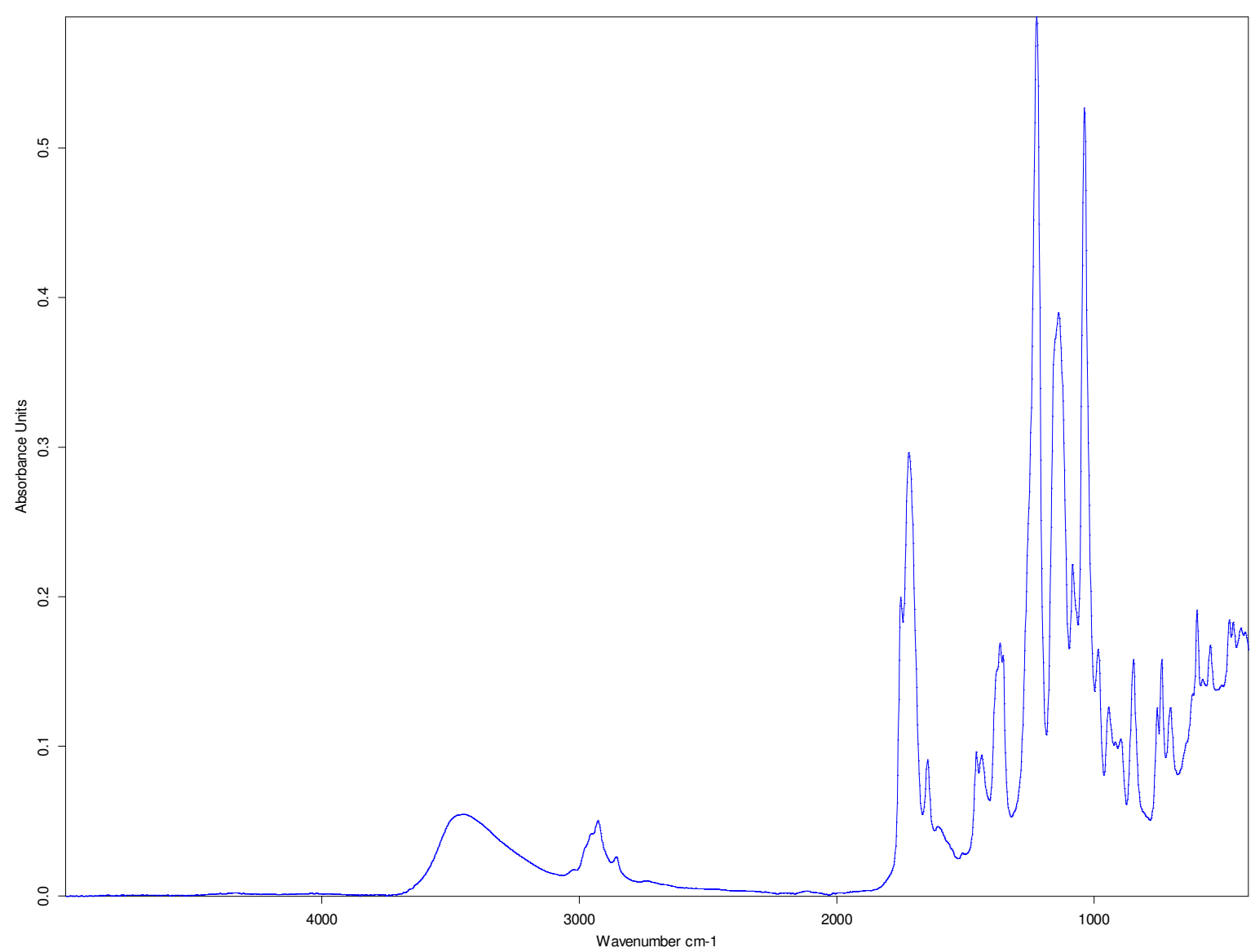

S15. HR-ESI-MS Spectrum of Compound 2

INULA D1AA CONE20_MEX3 copy 9 (0.170) AM2 (Ar.18000.0,0.00,0.00); Cm (1:10)

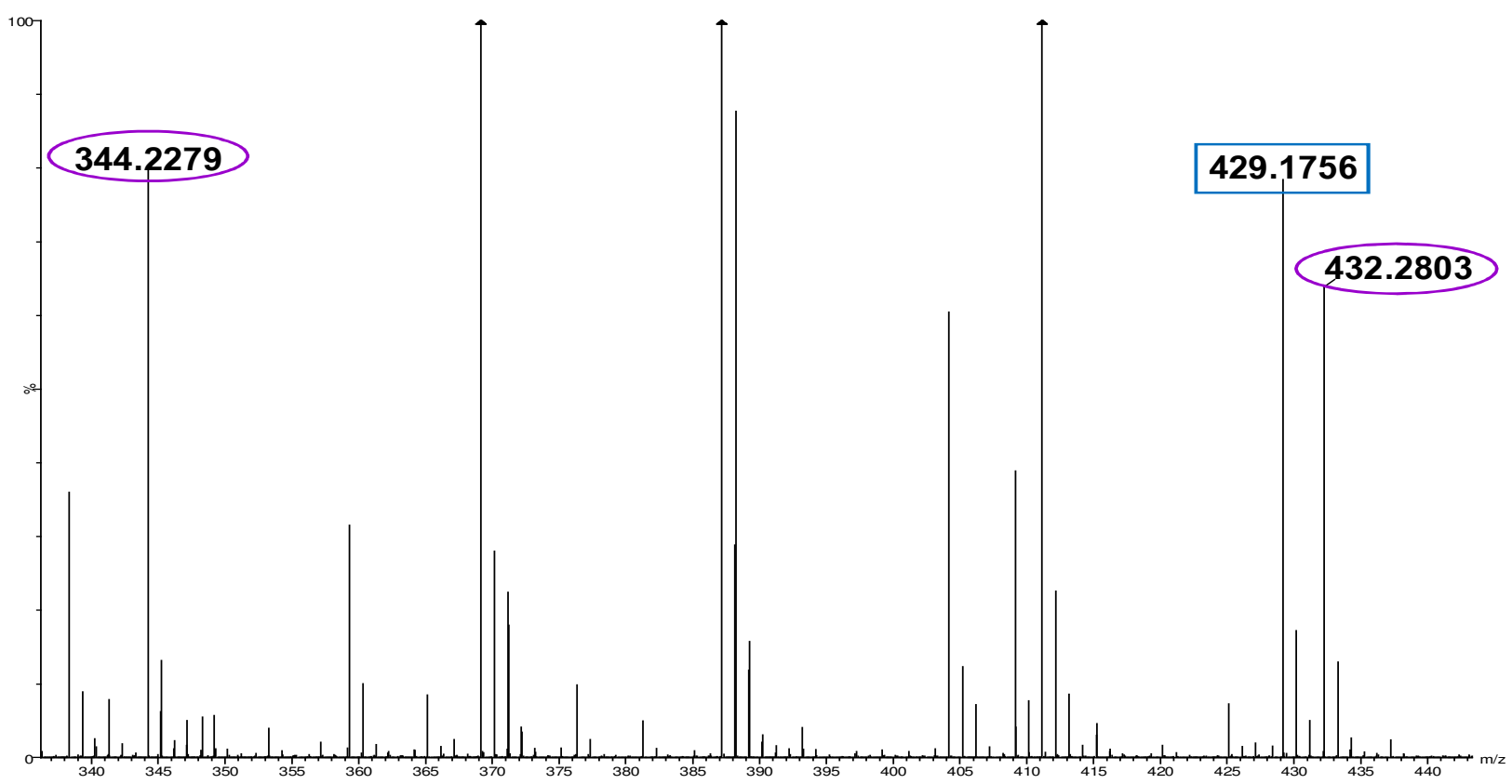

\begin{tabular}{|l|c|c|c|c|}
\hline & & $\mathrm{m} / \mathrm{z}$ & error $(\mathrm{mDa})$ & error $(\mathrm{ppm})$ \\
\hline Teoretical values & & 429.1755 & - & - \\
\hline \multirow{3}{*}{ Experimental values } & 1 & 429.1757 & +0.2 & +0.5 \\
& 2 & 429.1757 & +0.2 & +0.5 \\
& 3 & 429.1756 & +0.1 & +0.2 \\
\hline
\end{tabular}

For Compound 3: 
S16. ${ }^{1} \mathrm{H}$ NMR Spectrum (600 $\left.\mathrm{MHz}, \mathrm{CD}_{3} \mathrm{OD}\right)$ of Compound 3

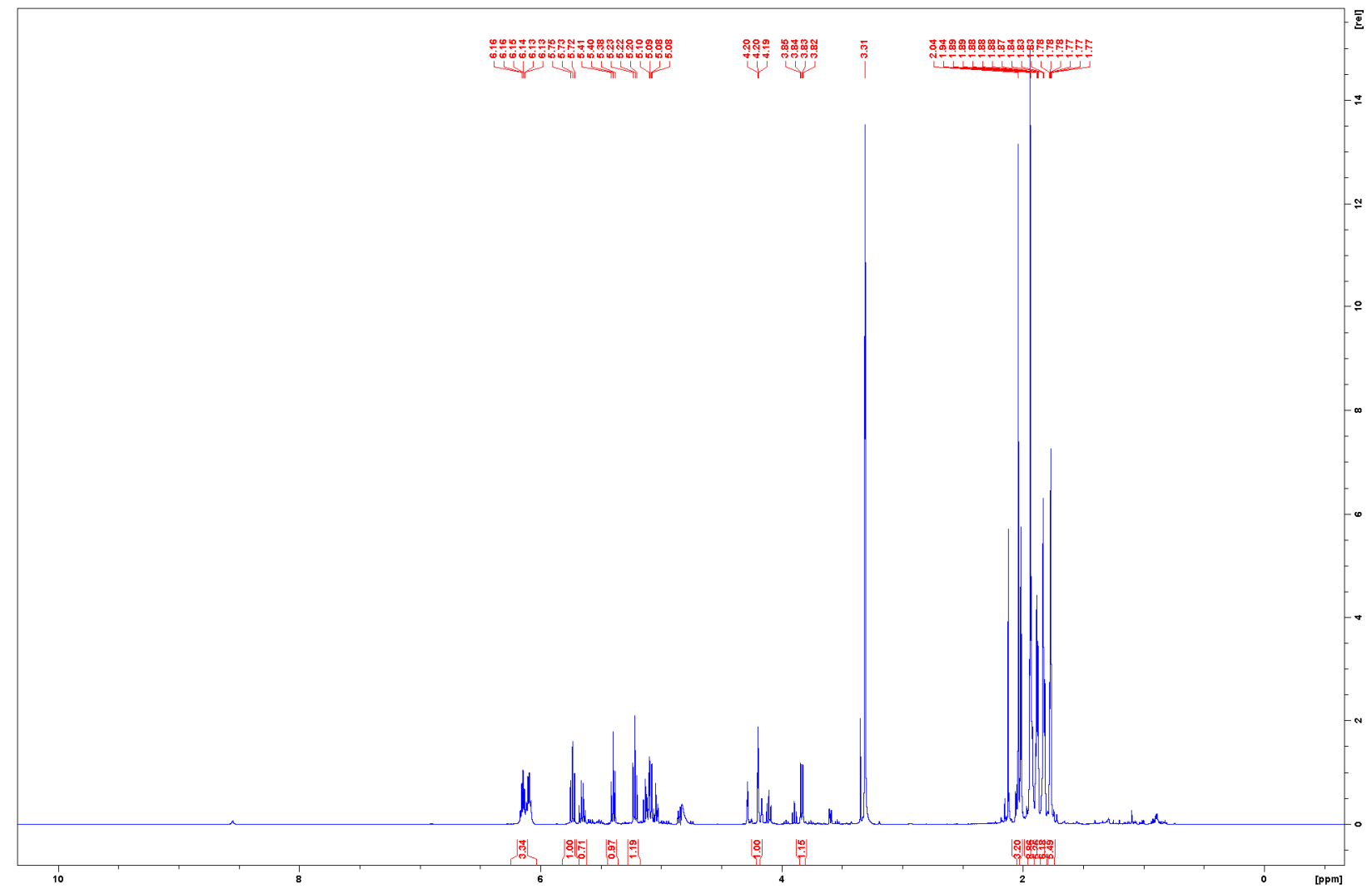

S17. ${ }^{13} \mathrm{C}$ NMR Spectrum (150 MHz, CD $\mathrm{CD}_{3} \mathrm{OD}$ ) of Compound 3

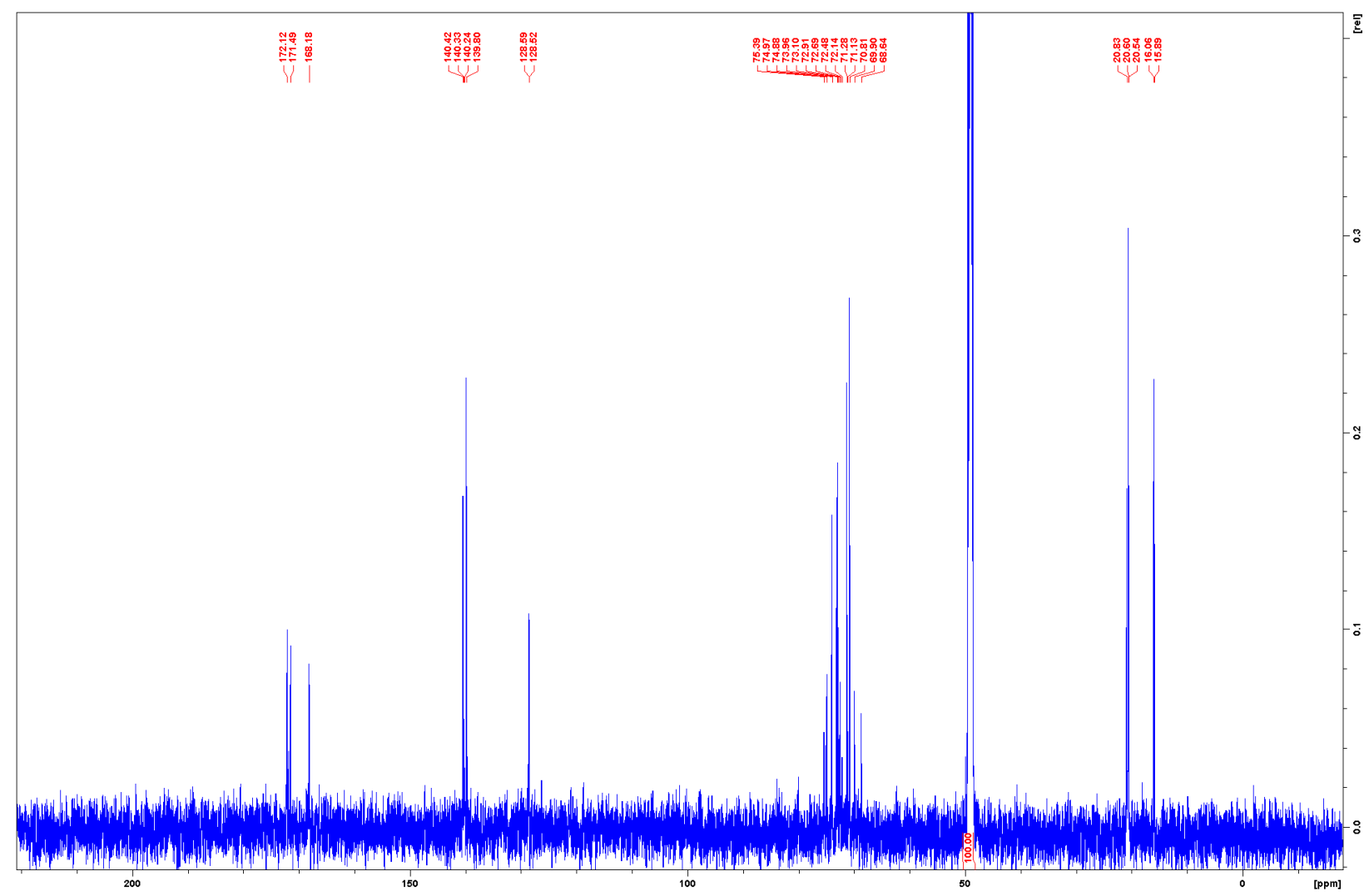

S18. HMBC Spectrum of Compound 3 


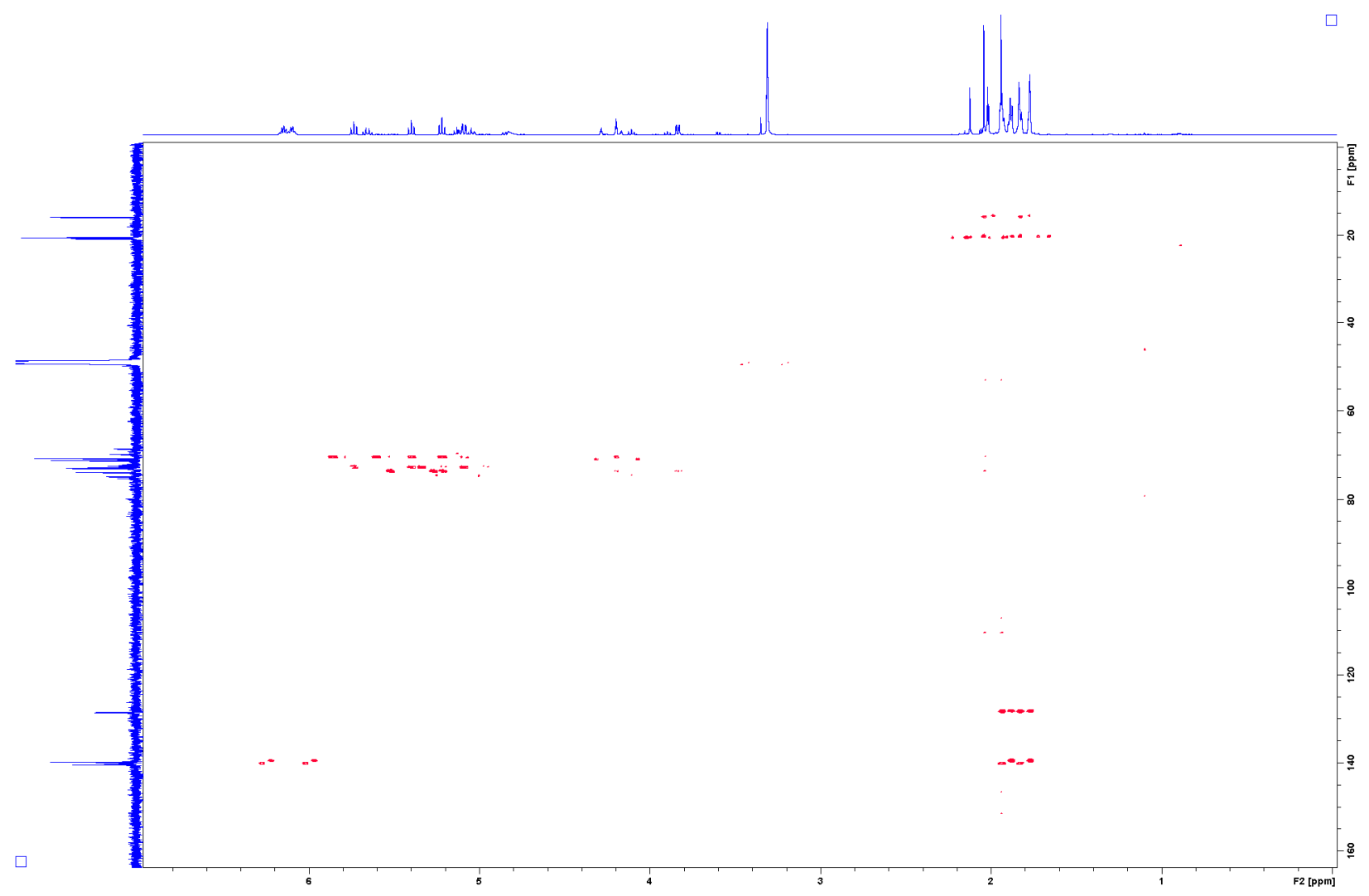

S19. ${ }^{1} \mathrm{H}-{ }^{1} \mathrm{H}$ COSY Spectrum of Compound 3

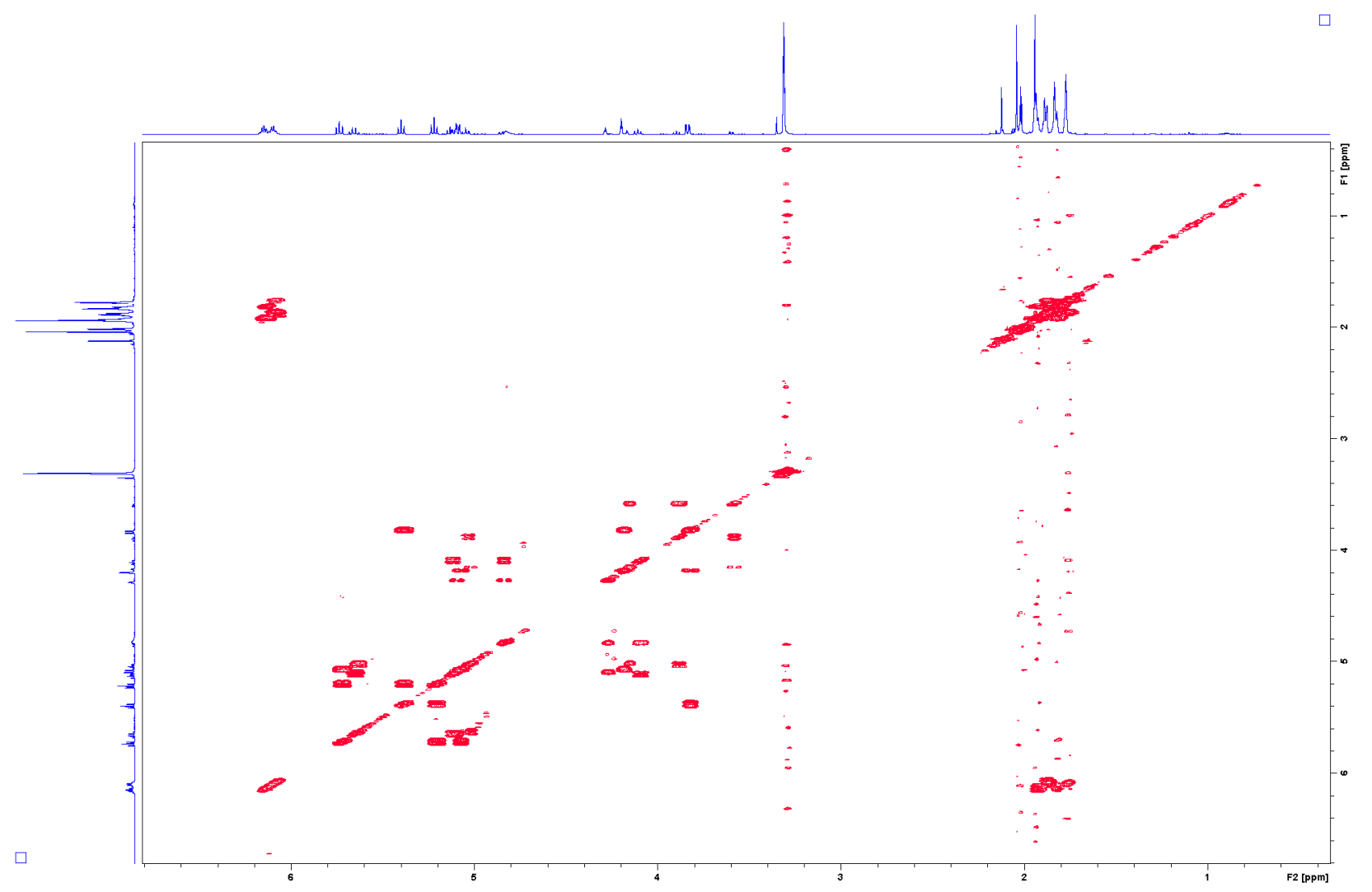


S20. NOESY Spectrum of Compound 3

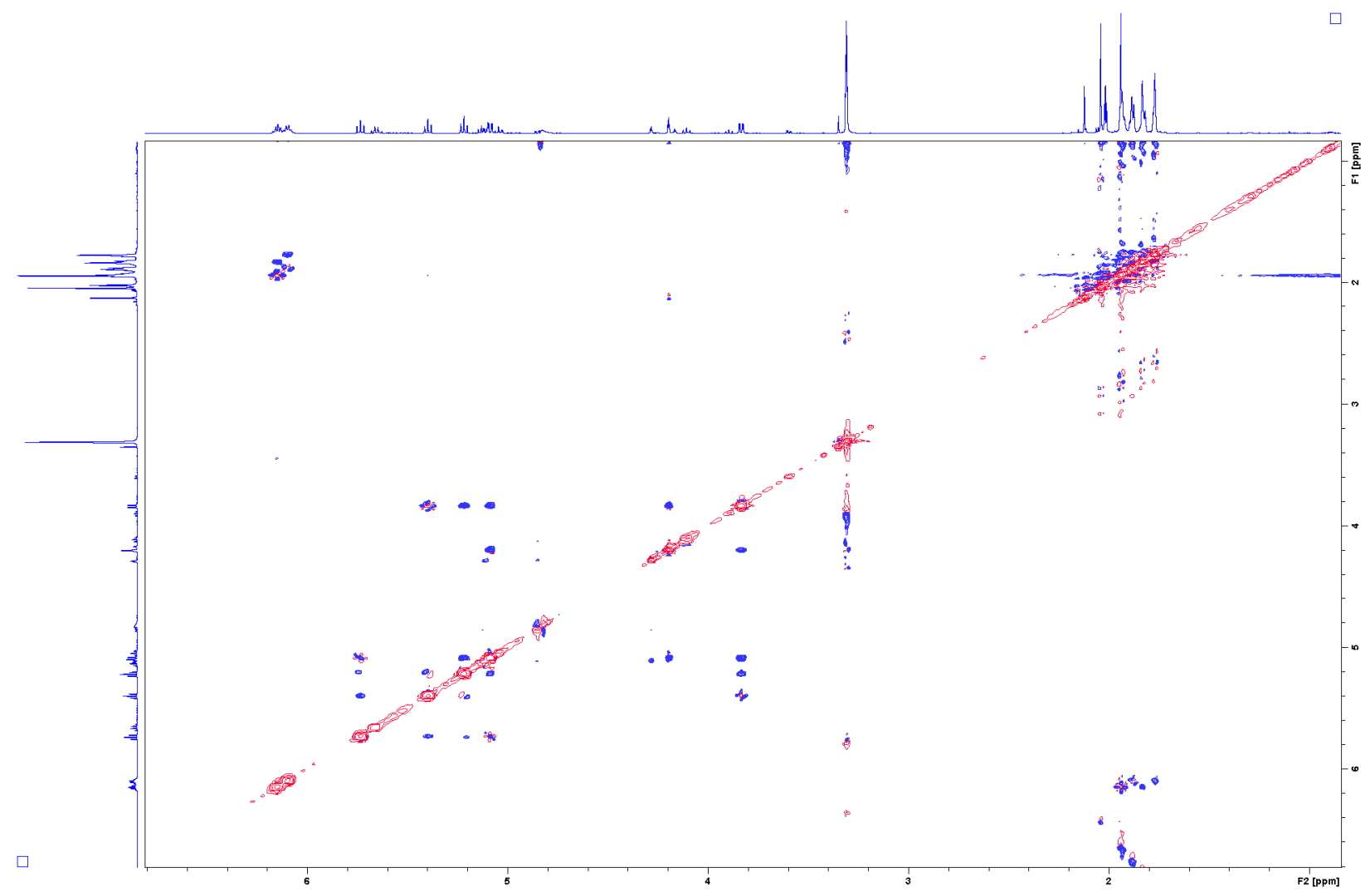

S21. IR Spectrum of Compound 3

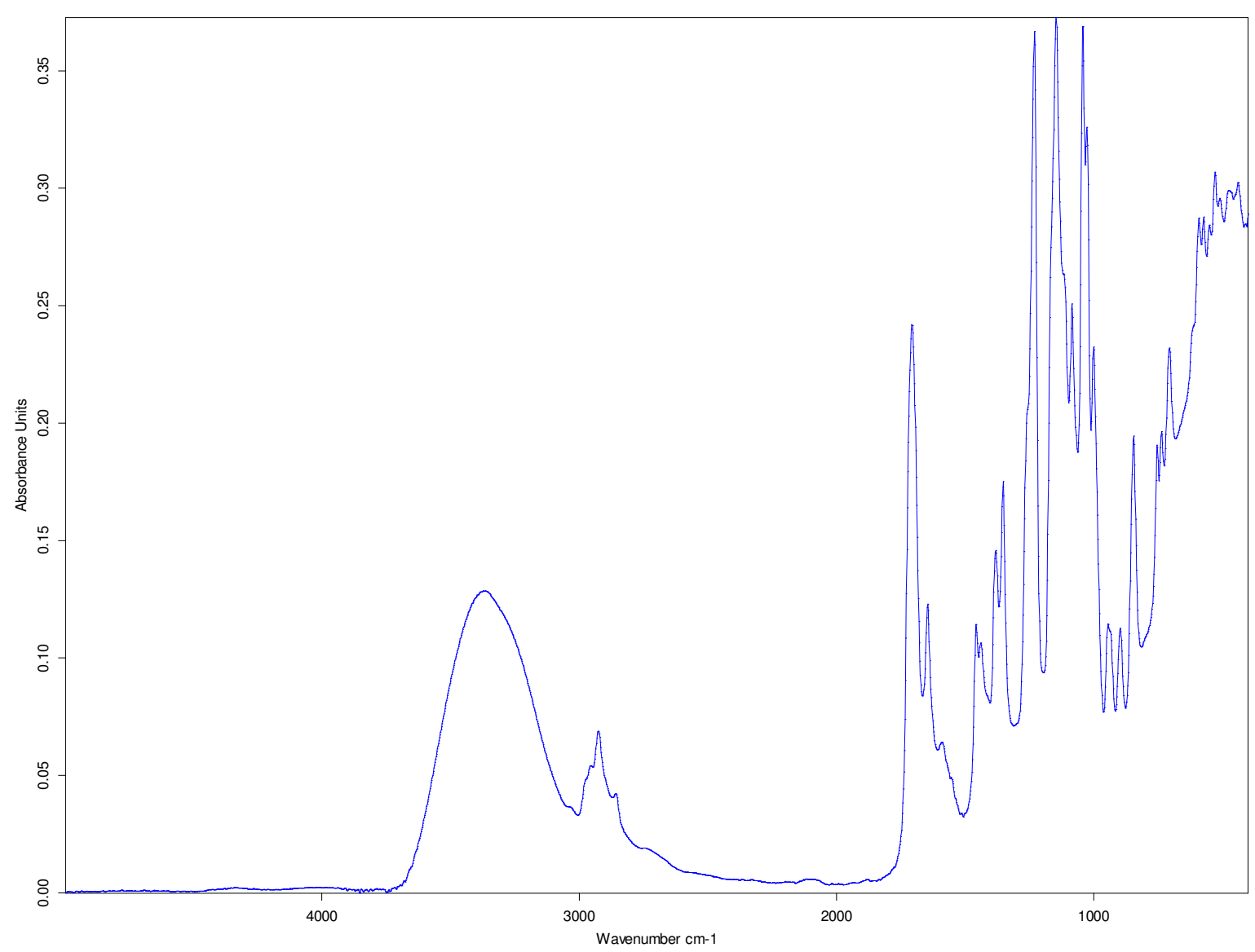


S22. HR-ESI-MS Spectrum of Compound 3

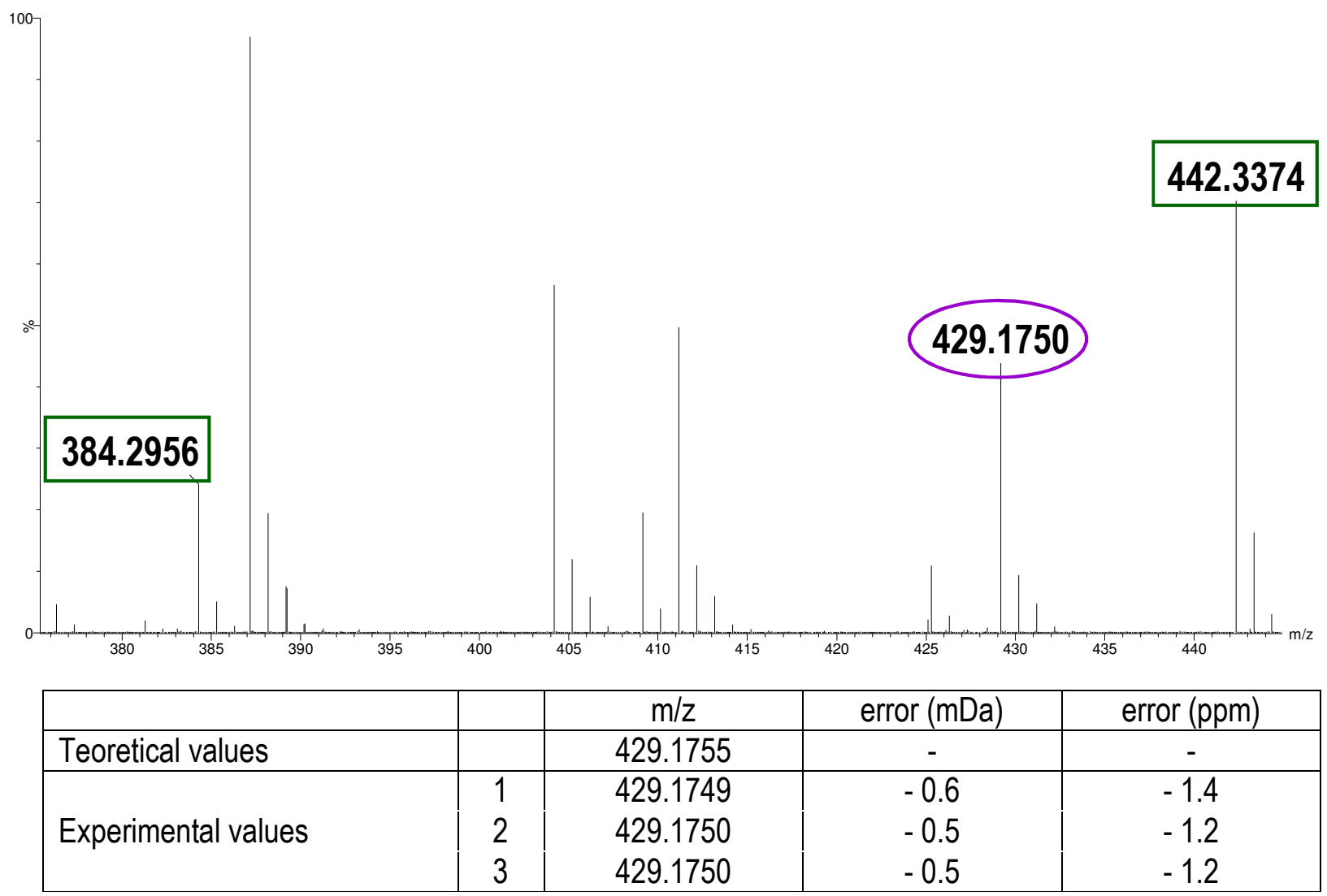

For mix of Compound 4 and Compound 5:

S23. ${ }^{1} \mathrm{H}$ NMR Spectrum (600 $\left.\mathrm{MHz}, \mathrm{CD}_{3} \mathrm{OD}\right)$ of mix of Compound 4 and Compound 5

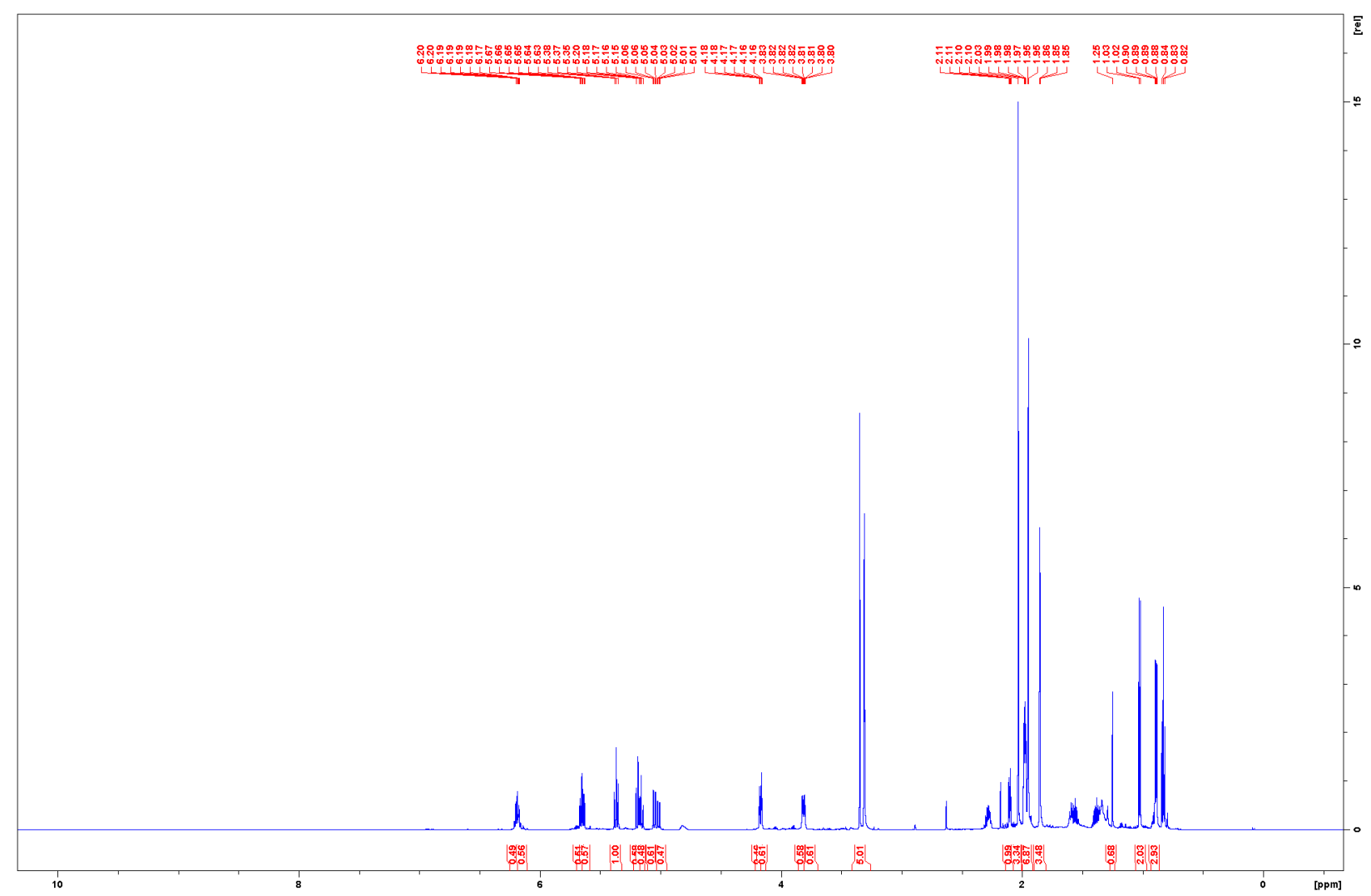

S24. DEPTQ135 Spectrum of mix of Compound 4 and Compound 5 


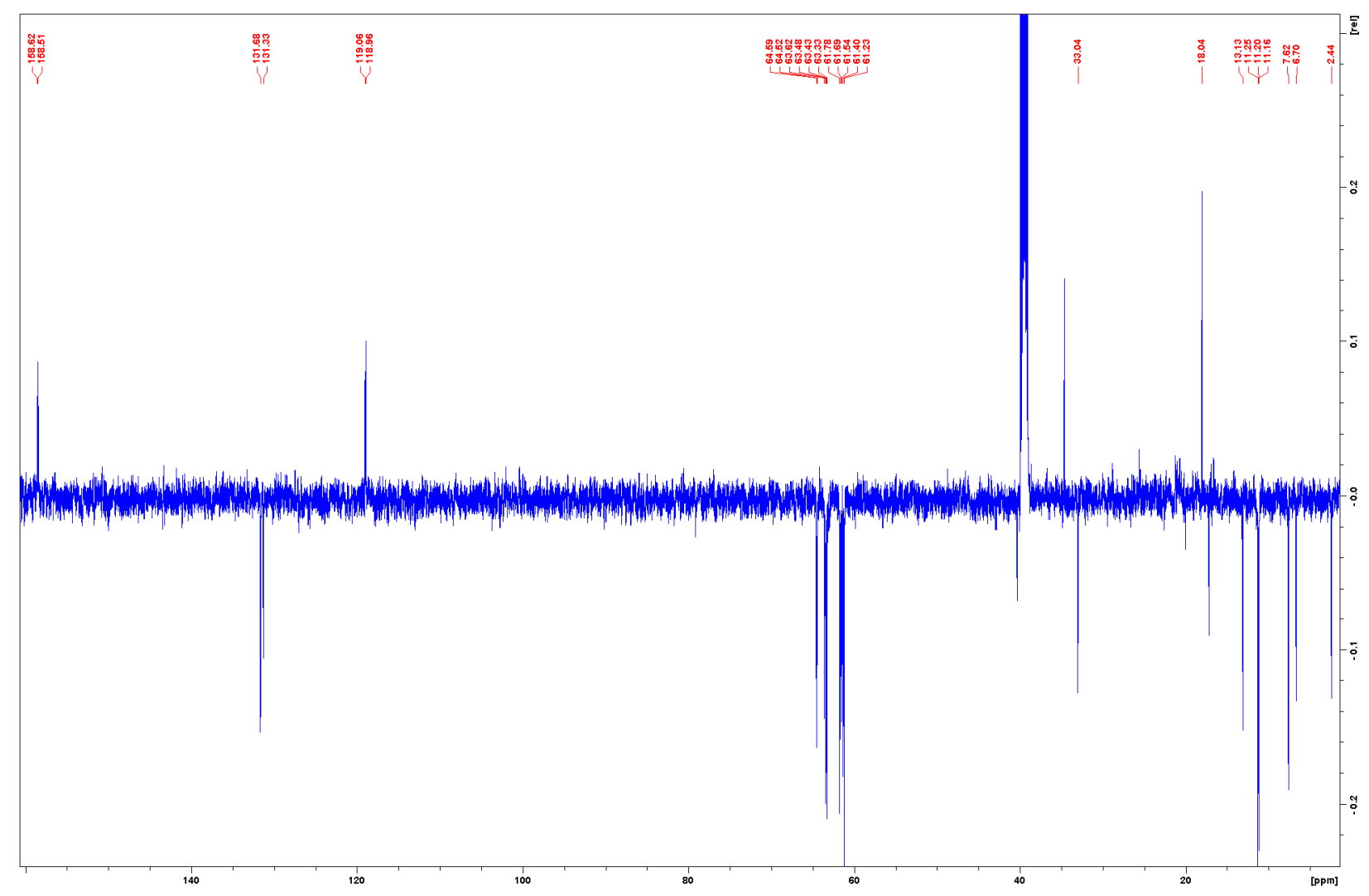

S25. HSQC Spectrum of mix of Compound 4 and Compound 5

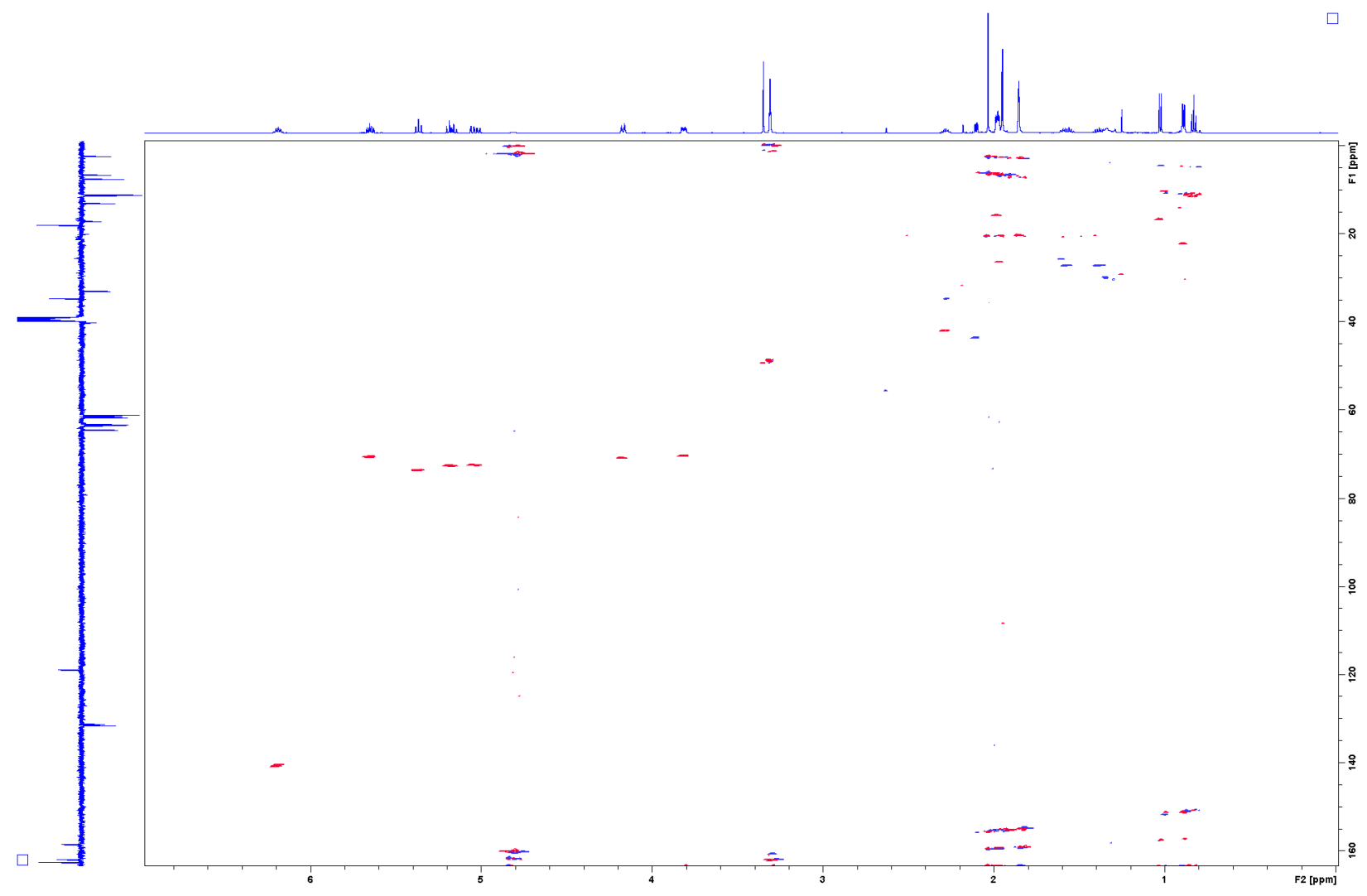

S26. HMBC Spectrum of mix of Compound 4 and Compound 5 


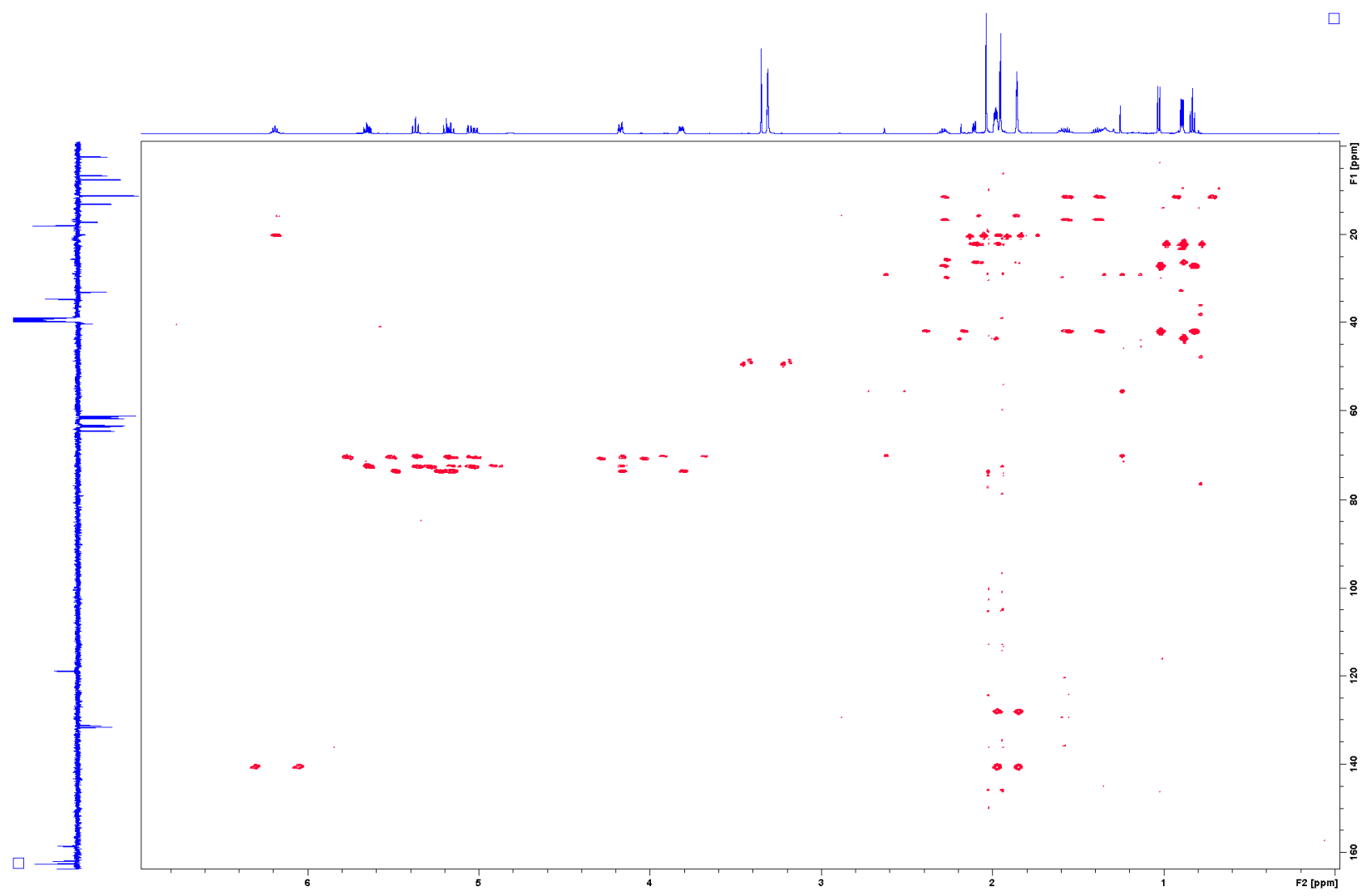

S27. ${ }^{1} \mathrm{H}-{ }^{1} \mathrm{H}$ COSY Spectrum of mix of Compound 4 and Compound 5

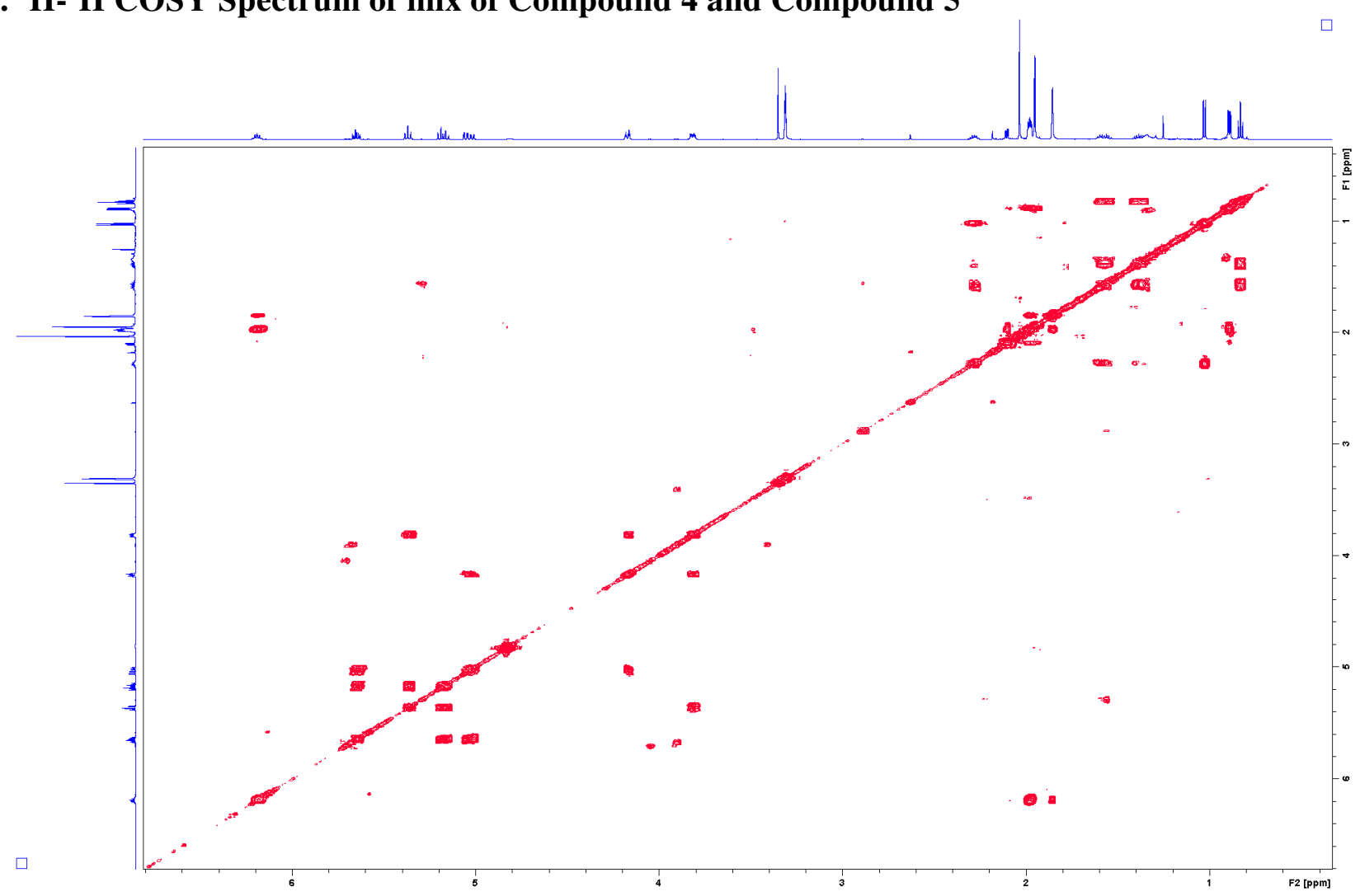

33 
S28. NOESY Spectrum of mix of Compound 4 and Compound 5

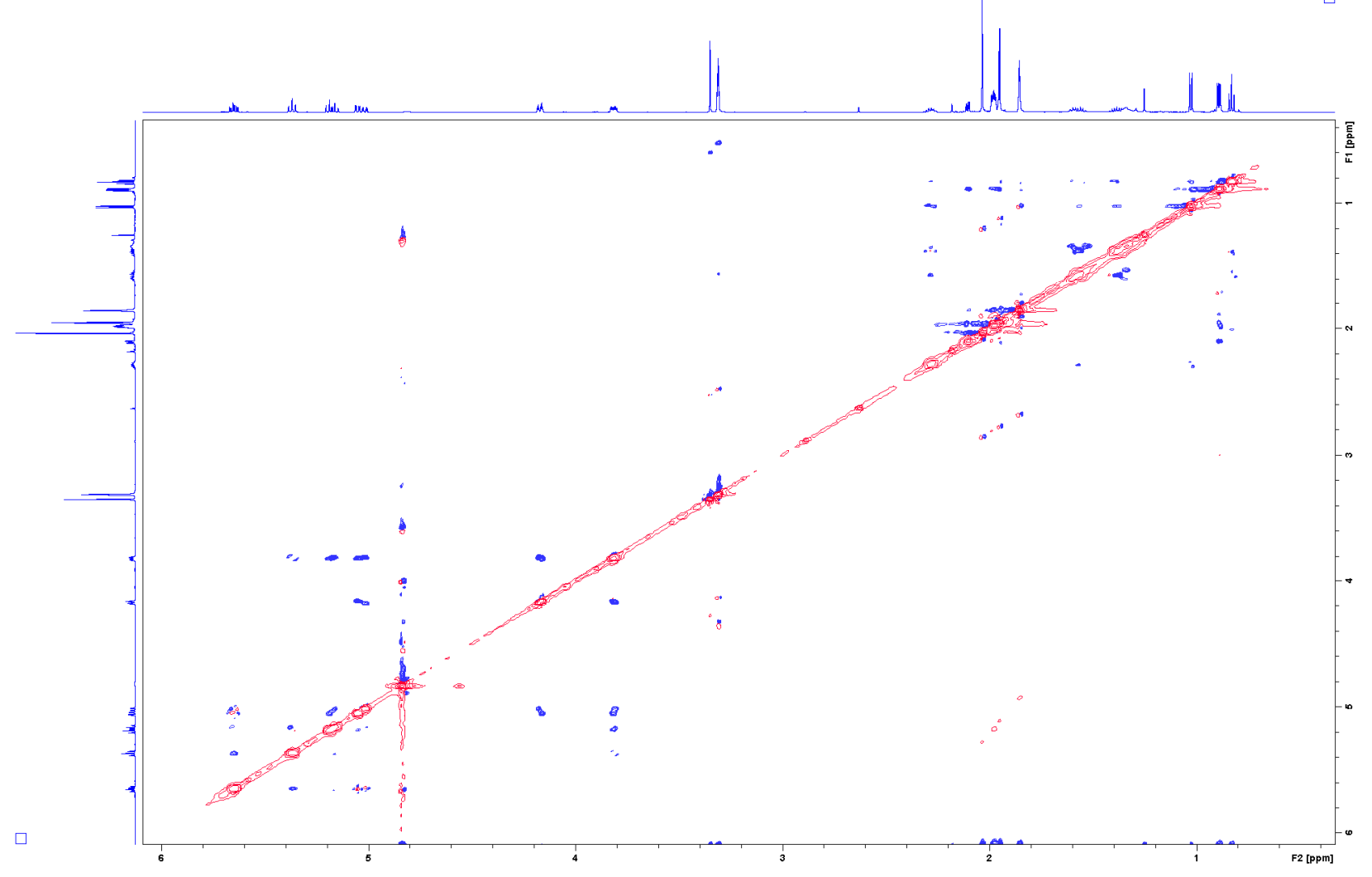

S29. IR Spectrum of mix of Compound 4 and Compound 5

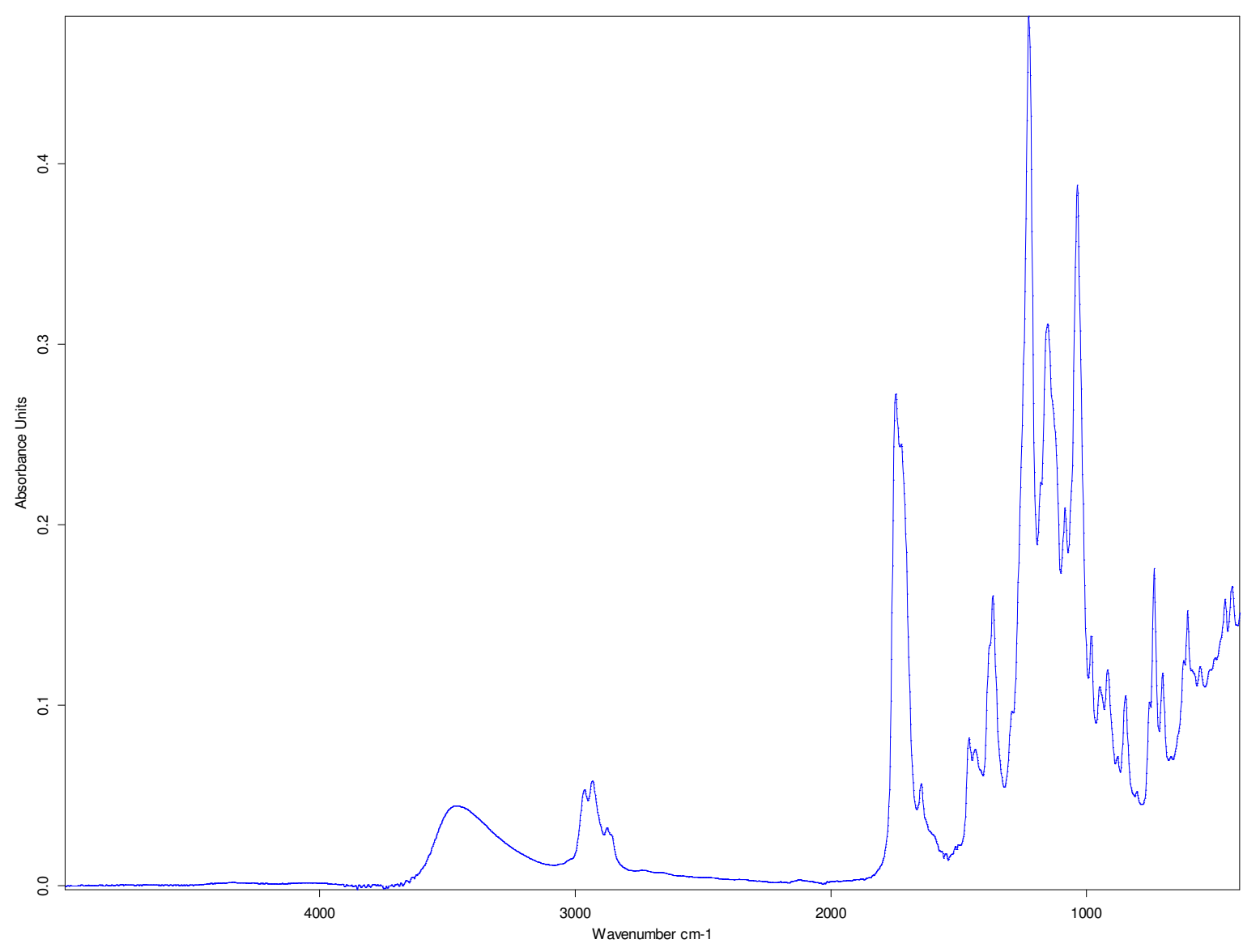


S30. HR-ESI-MS Spectrum of mix of Compound 4 and Compound 5

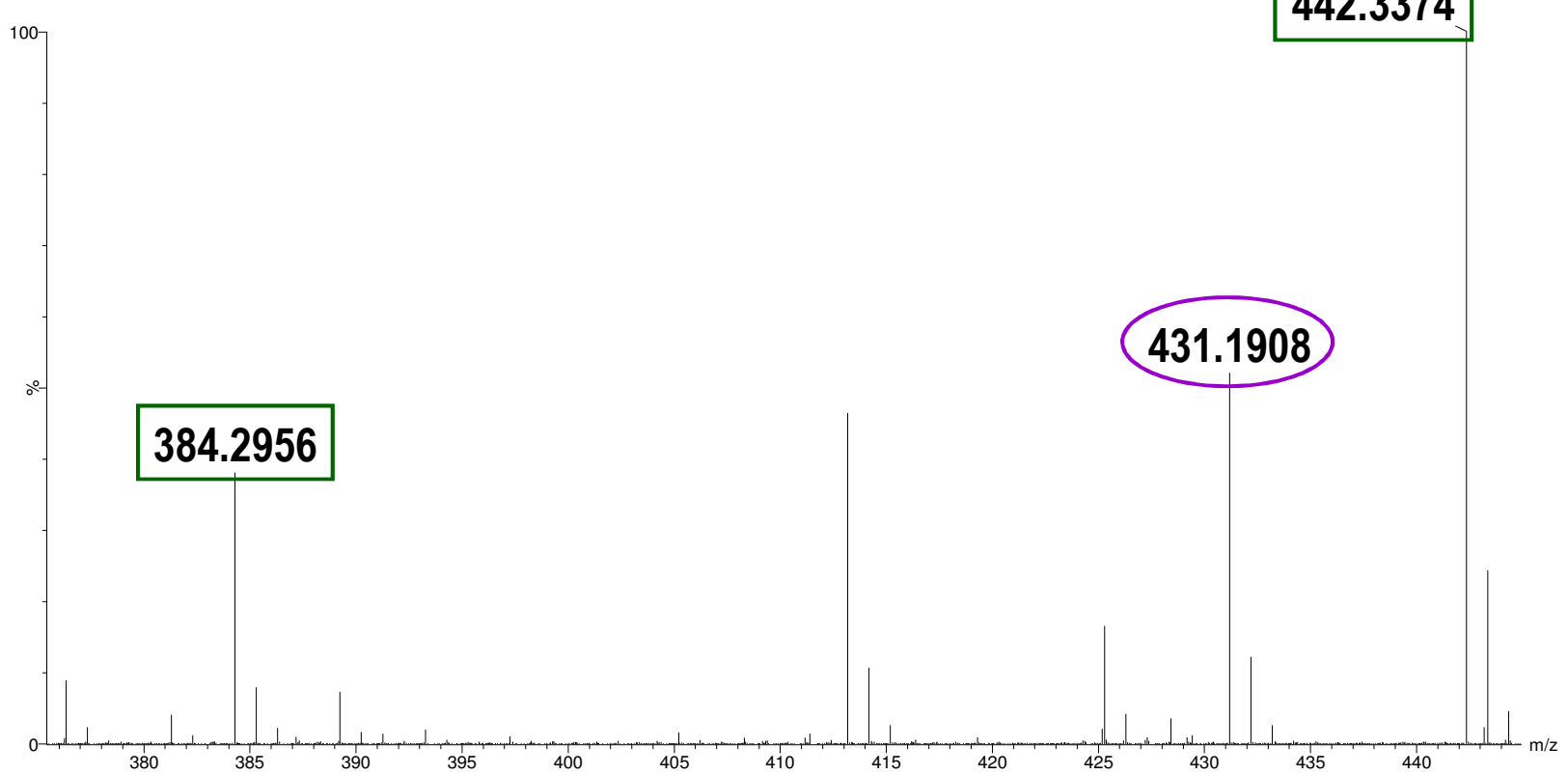

\begin{tabular}{|l|c|c|c|c|}
\hline & & $\mathrm{m} / \mathrm{z}$ & error $(\mathrm{mDa})$ & error $(\mathrm{ppm})$ \\
\hline Teoretical values & & 431.1912 & - & - \\
\hline \multirow{3}{*}{ Experimental values } & 1 & 431.1907 & -0.5 & -1.2 \\
& 2 & 431.1907 & -0.5 & -1.2 \\
& 3 & 431.1908 & -0.4 & -0.9 \\
\hline
\end{tabular}

